\title{
Archaeological Research at the Rowland Clark Site (41RR77), Red River County, Texas
}

Gegory Perino

Unknown

Follow this and additional works at: https://scholarworks.sfasu.edu/ita

Part of the American Material Culture Commons, Archaeological Anthropology Commons, Environmental Studies Commons, Other American Studies Commons, Other Arts and Humanities Commons, Other History of Art, Architecture, and Archaeology Commons, and the United States History Commons

Tell us how this article helped you.

This Article is brought to you for free and open access by the Center for Regional Heritage Research at SFA ScholarWorks. It has been accepted for inclusion in Index of Texas Archaeology: Open Access Gray Literature from the Lone Star State by an authorized editor of SFA ScholarWorks. For more information, please contact cdsscholarworks@sfasu.edu. 


\section{Archaeological Research at the Rowland Clark Site (41RR77), Red River County, Texas}

\section{Creative Commons License}

(c) (1) (8)

This work is licensed under a Creative Commons Attribution-NonCommercial 4.0 International License 


\section{Archaeological Research at the Rowland Clark Site (41RR77), Red River County, Texas}

\section{Introduction and Site Setting}

The Rowland Clark site is located in Red River County, Texas, on a prehistoric river channel of the Red River that has been intersected by a more recent channel of the river. It is approximately $16 \mathrm{~km}$ south of the Arnold Roitsch or Sam Kaufman (41RR16) site. The site had small Coles Creek and Early Caddoan period occupations, but the major occupation was of a McCurtain phase group of the Late Caddoan period. 1

The site has been in the Clark family for more than a century. The land the site is on is the property of Mr. Rowland Clark.

The site lies on a narrow alluvial terrace at the edge of the floodplain, and it is bounded on the north by a comparatively recent river bank with springs at the base (Figure 1). An older river bank is to the east, and to the west is a small range of sandy pimple mounds, some 5-6 feet tall. These pimple mounds may be ancient sand dunes. A shallow swampy depression, part of an older watercourse, lies between the sandy mounds and the site.

Soils at Rowland Clark consist of $0.75-1$ meter of sandy loam overlying $5-8 \mathrm{~cm}$ of a red gumbo-like clay, which in turn overlies a black gumbo clay deposit of unknown depth. These are favored agricultural soils because the gumbo hardpan retains water above it so that it is available to most plants when it is needed. This characteristic of the soil was detrimental to the preservation of site burials, artifacts, and faunal and floral remains.

The Rowland Clark site primarily contains a McCurtain phase village with one small plowed-down mound (ca. 1 meter in height). West of it was a broad, low, terrace rise where farmsteads and attendant house patterns were preserved. The mound and the village are approximately 200 meters southeast of what likely was the contemporary river bank; the river today is $1.2 \mathrm{~km}$ north and east of the site.

A small amount of artifacts were found on the site in the five years preceding Museum of the Red River excavations. The prehistoric artifacts included sections of small, thin clay pipestems, five celts, three celt preforms, cobble and anvil tools, pitted cobbles, lithic debris, a few pottery sherds, two stone cobble pottery trowels, three Caddoan hammerstones with faceted working ends, one edge-prepared tool used in chert knapping, one un-notched Mineral Springs knife, and 23 projectile points (one serrated Agee, nine Alba, two side-notched arrow points, seven Fresno and Maud, three corner-notched arrow points, and three Gary dart points).

The Agee arrow point, the Mineral Springs knife, and a few Coles Creek pottery sherds indicate that a small Coles Creek period/late Fourche Maline occupation (ca. A.D. $700-900$ ) was present on the alluvial terrace. No features or house sites were identified in our excavations for this occupation, or with the Early Caddoan period occupation represented by the Alba arrowpoints.

Early nineteenth century materials are present as well, namely: a pewter button with four holes, part of the base of a green wine glass bottle, and two pieces of hand-painted refined earthenware. This is the kind of material expected to occur on early Choctaw sites when they began to occupy the area across the Red River in southeastern Oklahoma, as well as on early frontier Anglo-American sites.

1 Perino's terminology has been revised and updated, following Schambach (1982), Story (1990) and Bruseth (1994), as follows: Perino uses Coles Creek, Gibson period, McCurtain Focus, and Fulton period, and I have changed them to Coles Creek (late Fourche Maline), Early Caddoan, McCurtain phase, and Late Caddoan period, respectively. 


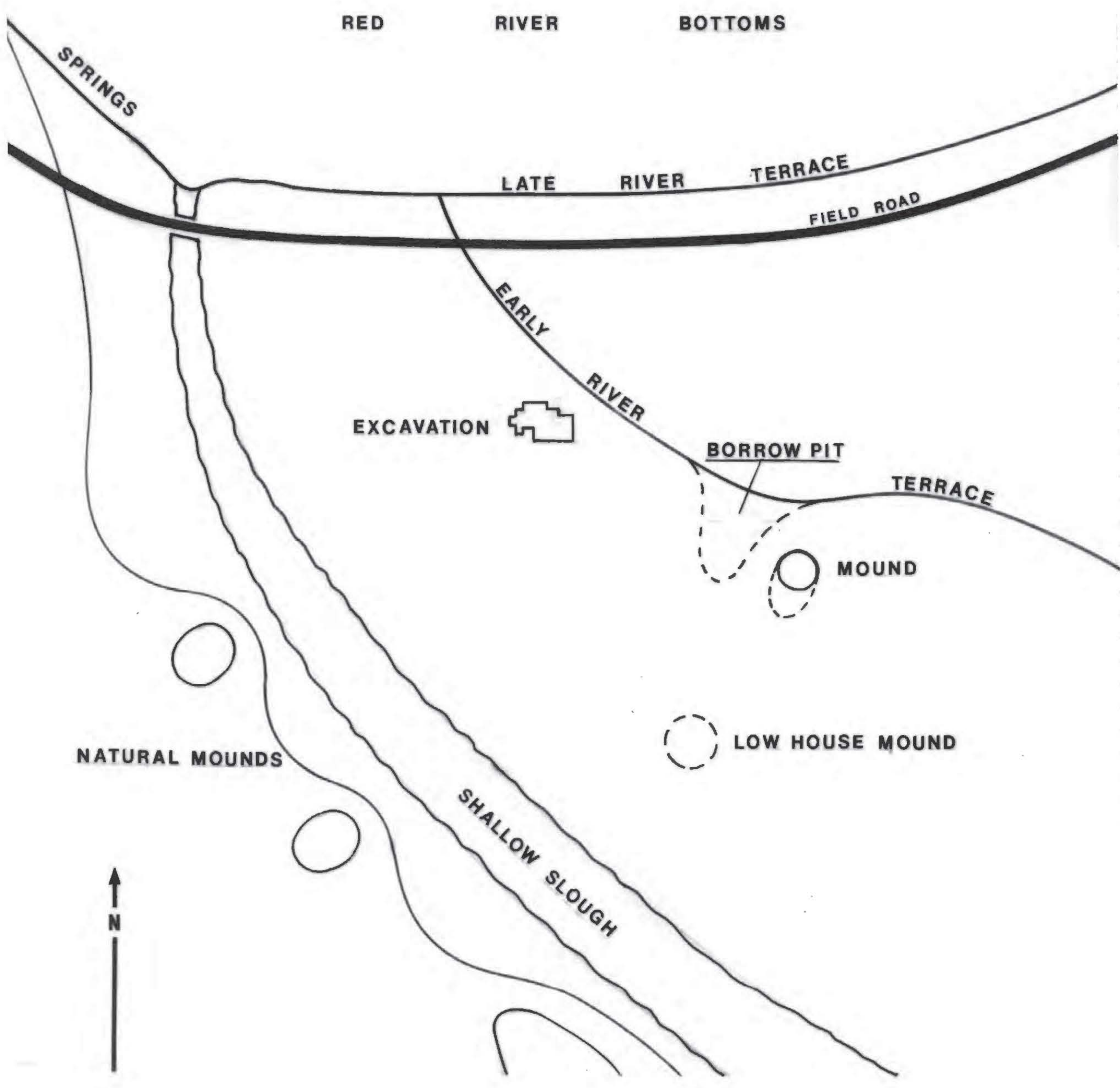

Figure 1. Map of the Rowland Clark site. 
Our excavations, which were conducted in April-May 1981, were located between the bank of the terrace and the mound. There, we found evidence of a lengthy and intensive Caddoan occupation with overlapping house patterns and two cemeteries; the habitation areas were identified by carbon-darkened soil, pottery sherds, and lithic debris (Figure 2). Unfortunately, the site has been cultivated for more than 100 years, and consequently much soil has eroded from it, also plowing up hearths and house floors.

The excavation area had many postmolds, smudge pits, and an assortment of small to large pits, and appears to have been the most intensively used part of the site. There were a few houses near the mound, but none showed the amount of activity as those in our excavation area.

The two cemeteries were discrete in that one contained the remains of early McCurtain phase burials and the other the remains of later McCurtain phase burials. The later graves were near the edge of the river terrace, but were more scattered than the early McCurtain graves; the later cemetery was also in an area that had early McCurtain phase house remains, which indicates some lapse of time between the use of the two cemeteries. These were farther back from the terrace edge and were closer together. Both cemeteries had a northeast-southwest orientation.

The placement of the cemeteries suggests that the Caddo occupants of the site were able to recognize the locations of earlier graves when they returned to habitation sites like Rowland Clark. Three factors may be pertinent: (1) Caddoan farmsteads were apparently surrounded by a hedge of trees, and many of the trees would still be living even after an absence of a century or more; (2) some Caddoan houses were of the sub-floor type, and a depression would still exist that marked its location; and (3) earlier graves would be evident by depressions created by the collapse of grave timbers upon which small piles of dirt had been placed. New graves were often excavated near the edges of the older cemeteries.

Judging from the associated artifacts, the earlier cemetery dates from ca. A.D. 1300-1450. The later McCurtain phase burials are estimated to date primarily from ca. A.D. 1550-1650, with a few (Burials 36-38) dating as late as A.D. 1700. The earlier graves were wider and longer, and contained more grave goods than did the post-A.D. 1550 burials, which became progressively narrower and had fewer grave goods by early historic times.

\section{The Rowland Clark Mound}

The mound was reported to me to have been excavated many years ago by an individual who claimed to have found a clay pipe in it. The Museum of the Red River tested the mound with a soil corer several years prior to 1981, and we determined that it had been plowed down over time to a height of ca. $90-120 \mathrm{~cm}$. It was about 12.2 meters in width and 18.3 meters in length, and it appeared as if the rear of the mound had a broad apron that was lower than the conical portion in the front.

Under the conical portion of the mound is a burned house, denoted by a thick layer of burned clay with its floor about $60 \mathrm{~cm}$ deep in the mound fill. The apron portion is nearly flat, and when probed a group of five vessels were located only a few $\mathrm{cm}$ below the plow zone; the plow had damaged the vessels slightly.

The vessels may have marked a grave, although no human remains were noted. The vessel types can be attributed to the late McCurtain phase, ca. A.D. 1600. The vessels consisted of:

o an Emory Punctated jar with castellated rim and saddle-like handles; a short appliqued strip extends vertically onto the shoulder below each handle.

o a red, conical Simms Engraved bowl. 


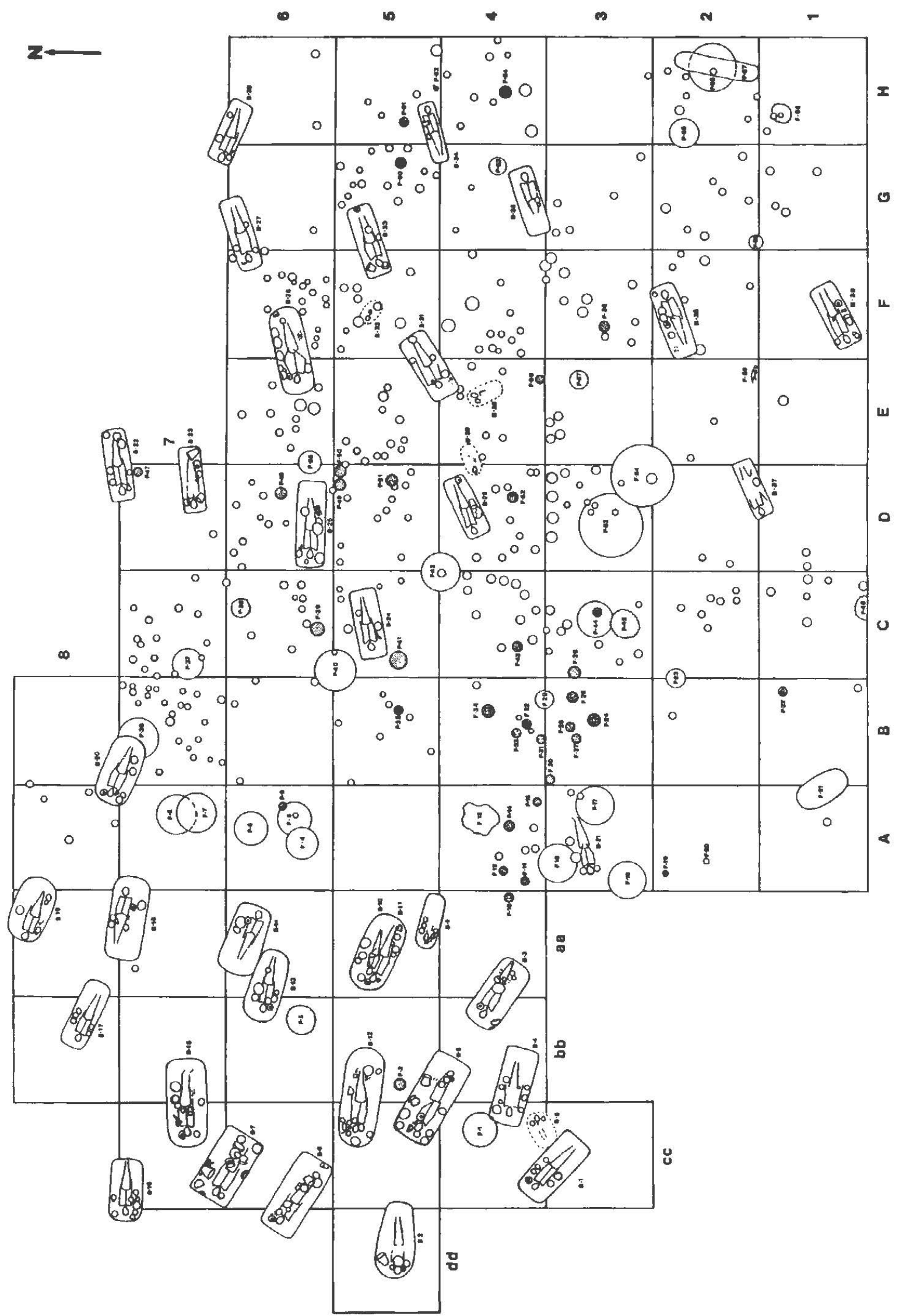

Figure 2. Plan of Excavation Area at Rowland Clark. 
o a V-shaped black bowl with an Avery Engraved sunrise motif repeated five times on the sides, and spaced by large blank circles and cross-hatched panel dividers.

o black Avery Engraved carinated bowl with red pigment in the engraved lines; the decoration consisted of cross-hatched panel dividers and four groups of nested circles with a toothed circular sunray design in the center of each group, and a small circle inside the sunray circle; and

o a black, polished, vase-like Avery Engraved bowl with three decorative panels (notched or toothed scrolls filled with hatchured lines), with circles and cross-hatching in the panel dividers. It has an everted, castellated rim with saddle-like handles, and there are three engraved lines on the outer rim surface.

\section{Excavations}

Our excavations were conducted in 10 foot squares (3.05 meters square) that were taken to the sterile subsoil. Squares were assigned alphanumeric designations (i.e., 1-8 from south to north, and A-H from west to east as well as aa-dd from east to west) (see Figure 2). After the plow zone and A-horizon from the first four squares was removed and screened, it became apparent that very little cultural material was to be found other than cultural features From that point, the excavations in the other 6610 foot squares proceeded to a depth of ca. $61 \mathrm{~cm}$, and identified features were recorded and excavated; in most cases, once the plow zone and some of the A-horizon was removed, features were recognizable.

Based on our probing, we expected to demarcate a late McCurtain phase cemetery near the edge of the terrace; the early McCurtain phase cemetery was unanticipated. We located this group of graves (see Figure 2) where Burial 21 was located when our excavations were extended to include a previously identified burned Caddoan house area.

\section{Burial Features}

Burial features were recognizable because the grave pits had been excavated through the sandy loam and red clay into the black gumbo, and the red clay mottling marked the feature fill against the tan or buff-colored subsoil. Once the red clay mottles in the black gumbo were removed, the complete outline of each burial pit was disclosed. Based on excavations at the Haley site in southwest Arkansas (Perino 1967), the aboriginal digging of the pits through the gumbo soils was accomplished by excavating a trench along one wall $12-15 \mathrm{~cm}$ deep, then driving a wood stake into the soil near the trench to break out chunks of the gumbo; these chunks then became mixed in the sandy backfill of the graves.

The 39 burials excavated at Rowland Clark were found in two cemeteries: Burials 1-21 in the western part of the excavations, dating from ca. A.D. 1300-1450, and Burials 22-39 in the eastern part of the grid, dating from ca. A.D. 1550 to near A.D. 1700; Burials 36-39 date after ca. A.D. 1650.

The earliest burials were in deep $(97-158 \mathrm{~cm})$, wide $(92-123 \mathrm{~cm})$, and long $(200-$ $276 \mathrm{~cm}$ ) grave pits, with squared to rounded ends. Based on the shape or opening outline, it is likely that some of the graves may have been excavated by the same individuals: Burials 1, 3-4, and 8 (square-ended) and Burials 9-11 and 13 (rounded ends). The large grave pit size was the result, in part, of the area needed to accommodate the many ceramic vessels that often accompanied the early McCurtain phase burials. The late McCurtain phase burials were narrower and shorter (Burials 22-35 were $102 \mathrm{~cm}$ deep, $51-92 \mathrm{~cm}$ wide, and 179-248 cm wide), and they also contained fewer grave goods. Burials 36-39 ranged from $95-121 \mathrm{~cm}$ in depth, $59-77 \mathrm{~cm}$ in width, and $174-215 \mathrm{~cm}$ in length. 
In general, the skeletal material was in poor condition (see Loveland, Appendix 2, this volume) because the adult burials were placed in pits within a water-saturated black clay gumbo stratum that dissolved many of the bones (Figure 3). The burials of children were usually associated with house floors, and were placed in shallow pits within the sandy loam stratum. They were poorly preserved as well, probably because of bioturbation and rodent activities.

The burials are individually described in this section of the report. Information provided on each of the burials includes age, provenience, depth, grave size, head orientation, and grave good inclusions.

Burial 1

Age: Adult

Provenience: $3 c c, 4 c c$

Depth: $113 \mathrm{~cm}$

Grave size: $97 \times 220 \mathrm{~cm}$

Head Orientation:Northwest

Grave Goods:Avery Engraved bottle near left shoulder and jaw; three thick, plain V-shaped bowls near left arm; two thin, V-shaped bowls with four rim lugs, one found near left arm (see Figure 16c) and the other near the right wrist; and an engraved globular bowl near the right humerus (see Figure 16b).

\section{Burial 2}

Age: Adult

Provenience:5dd

Depth:97 cm

Grave Size: $113 \times 217 \mathrm{~cm}$

Head Orientation:West

Grave Goods:Three Scallorn sattler arrow points near left knee; Simms Engraved red conical bowl near the left shoulder; a small Nash Neck Banded jar left of the skull; a Clark Engraved bowl on the face, and another near the right shoulder; and a plain bottle on the right side of the skull.

\section{Burial 3}

Age: Adult

Provenience: $4 \mathrm{aa}, 4 \mathrm{bb}$

Depth: $148 \mathrm{~cm}$

Grave Size: $100 \times 200 \mathrm{~cm}$

Head Orientation: Northwest

Grave Goods:A late form of East Incised bowl near the right side of the skull; an Avery Engraved bottle between the left shoulder and jaw; a large, red Avery Engraved bowl resting in the stomach area (see Figure 11a) and a red conical Avery Engraved bowl on the left femur; deer ulna tool in northwest part of grave, but ca. $26 \mathrm{~cm}$ above the floor; four Scallorn sattler arrowpoints and a Haskell-like arrowpoint (see Figure 5a) near the knees; small, plain bowl (with rim castellations) against the right tibia (see Figure 15h), and a globular bowl (with castellations) (see Figure 15d) as well as a red conical bowl (with chamfered rim) near the tibia; gray pigment near the plain red bowl; and a small Avery Engraved castellated bowl containing red and green clay pigment.

\section{Burial 4}

Age: Adult

Provenience: $4 \mathrm{bb}$

Depth: $108 \mathrm{~cm}$

Grave Size:92 x $225 \mathrm{~cm}$

Head Orientation:West-Northwest 

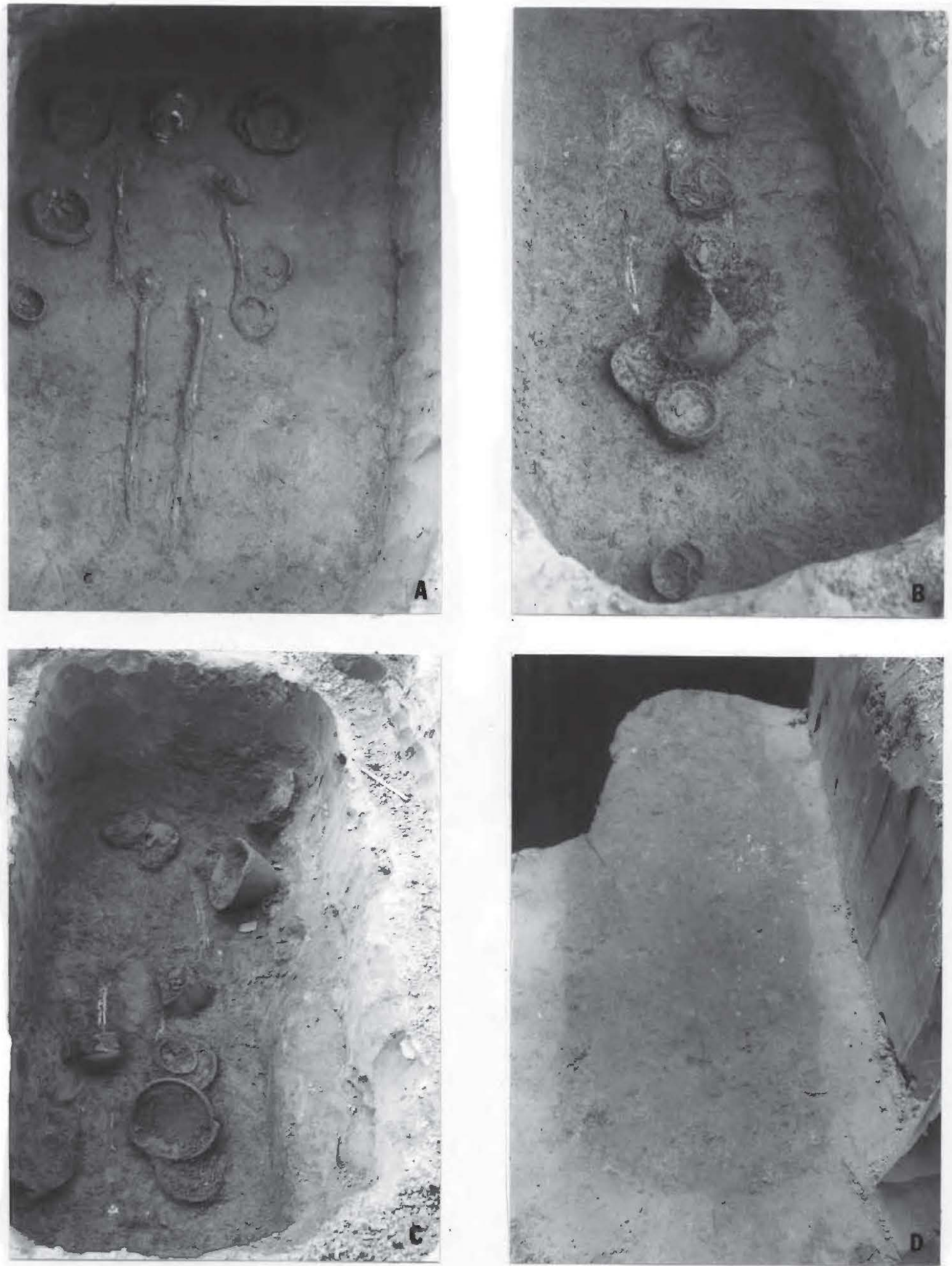

Figure 3. McCurtain phase burials from the Rowland Clark site: A, Burial 4; B, Burial 6; C, Burial 8; D, Burial 28, showing pit outline halfway to the bottom. 
Grave Goods:Emory Punctated-Incised carinated bowl near left shoulder (see Figure 9c); two shallow Avery Engraved bowls near the left hand (see Figure 13e) and a Avery Engraved bottle base (reworked for use as a bowl) near the left humerus and shoulder; Clark Engraved bowls near right shoulder and elbow; a Nash Neck-Banded jar by the right hand; and a lump of green clay pigment between the right hand and femur.

\section{Burial 5}

Age:Child

Provenience: $4 \mathrm{cc}$

Depth: $97 \mathrm{~cm}$

Grave Size: $62 \times 108 \mathrm{~cm}$

Head Orientation:East-Northeast

Grave Goods:Two small jars, one with rim castellations and strap handles, the other Nash Neck-Banded.

\section{Burial 6}

Age:Adult

Provenience:6cc

Depth: $115 \mathrm{~cm}$

Grave Size: 100 x $246 \mathrm{~cm}$

Head Orientation:Northwest

Grave Goods:Six arrowpoints (three Scallorn coryell, two corner-notched (see Figure 5c), and one Washita peno) near the left shoulder; Avery Engraved bottle by the left side of the skull; a plain flared and scalloped rim bowl (see Figure 9d) near left shoulder; Clark Engraved bowl (with four rim lugs) resting in the stomach area (see Figure 13a), and another between the legs (see Figure 13d) and near the left tibia; a small, plain carinated bowl (with strap handles and rim castellations) on the left femur, another plain bowl at the feet and two small V-shaped bowls below the feet; a large, red conical bowl resting on the upper tibia; and a large Nash Neck-Banded jar near the right foot. A ball of yellow clay was lying on the chest area.

\section{Burial 7}

Age:Adult

Provenience:6cc, $7 \mathrm{cc}$

Depth: $133 \mathrm{~cm}$

Grave Size: 123 x $217 \mathrm{~cm}$

Head Orientation:Northwest

Grave Goods:A plain red bottle and bowl (see Figure 10a) near left shoulder and head; Avery Engraved carinated bowl at the right knee (see Figure 10d), another near the right foot, and a large Avery Engraved conical bowl by the left elbow (see Figure 11b); a red, conical bowl resting on the left femur, and part of another conical bowl above the left side of the head; nested Clark Engraved bowls near the left knee (see Figure 13b and 14a), and a third Clark Engraved near the right pelvis; a large Simms Plain bowl resting on the left foot; two poorly preserved partial vessels near the feet hat resemble pot covers; a small celt (Figure 4r); two clay pipes (see Figure 16b, d); four arrowpoints (two Scallorn sattler and two Washita peno); finally, a sandstone abrader, an unidentified piece of limestone, a deer jaw pick and a poorly preserved deer ulna tool were found together with eight novaculite and siltstone flakes by the left elbow.

\section{Burial 8}

Age:Adult

Provenience: $4 b b, 5 b b, 5 c c$

Depth: $118 \mathrm{~cm}$

Grave Size: 115 x $261 \mathrm{~cm}$ 


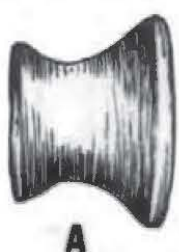

A

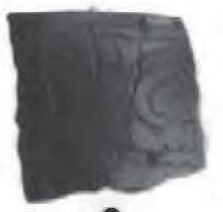

C

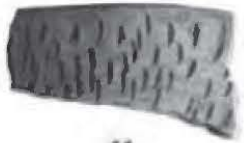

K

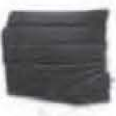

D

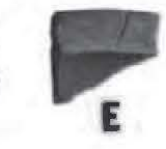

E

$\mathbf{F}$

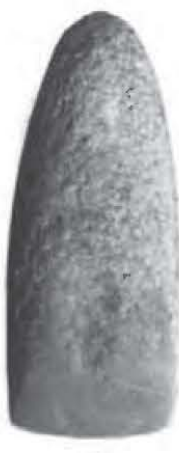

G

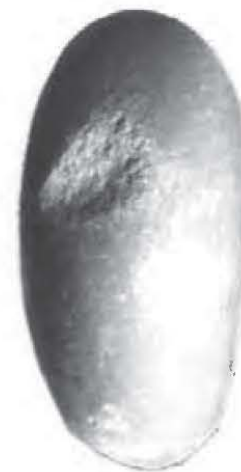

H

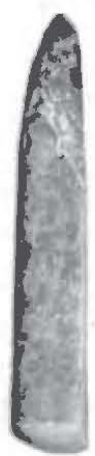

I

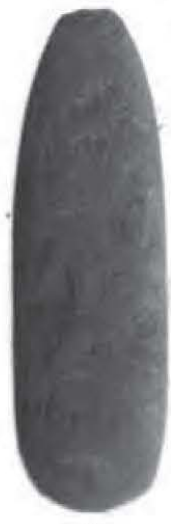

J
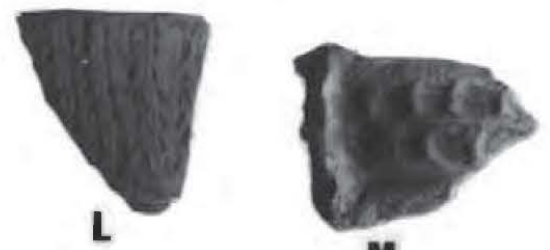

M

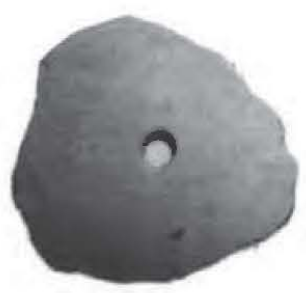

N

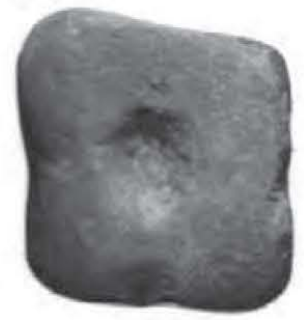

0
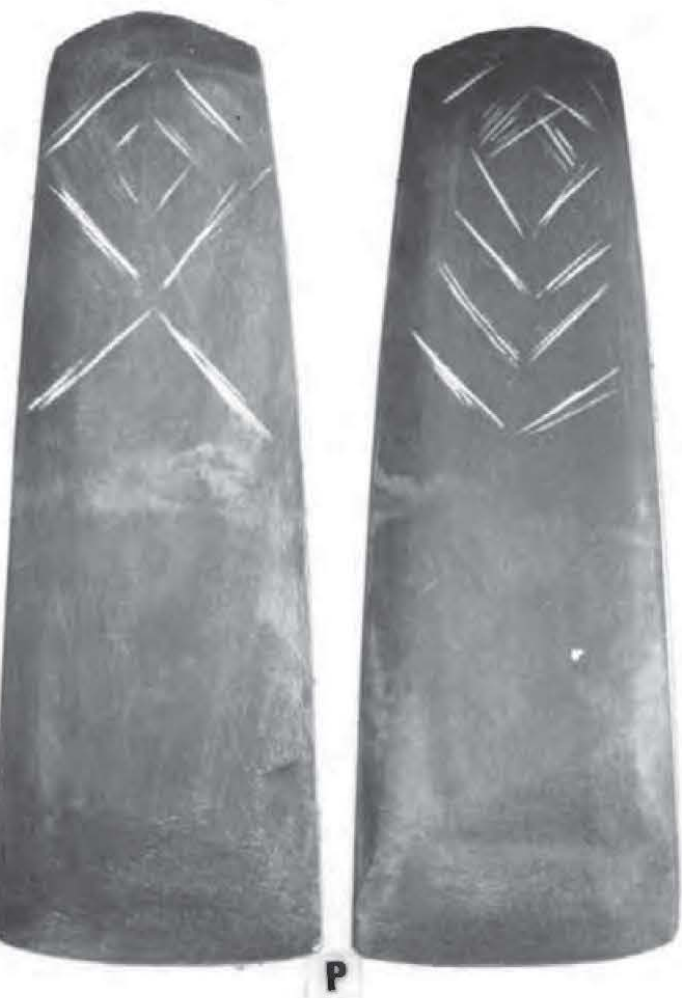

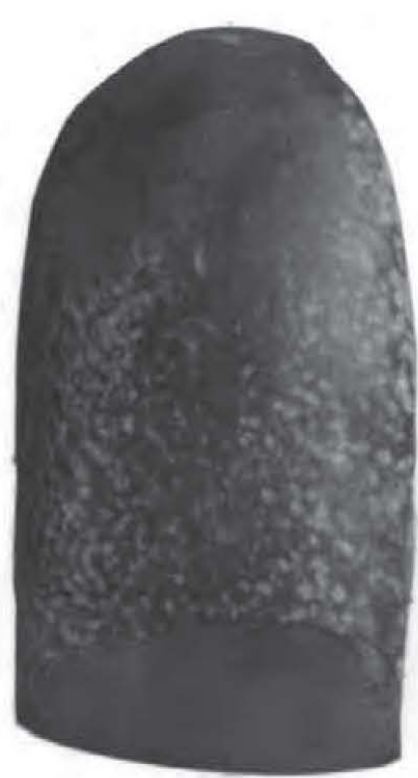

Q

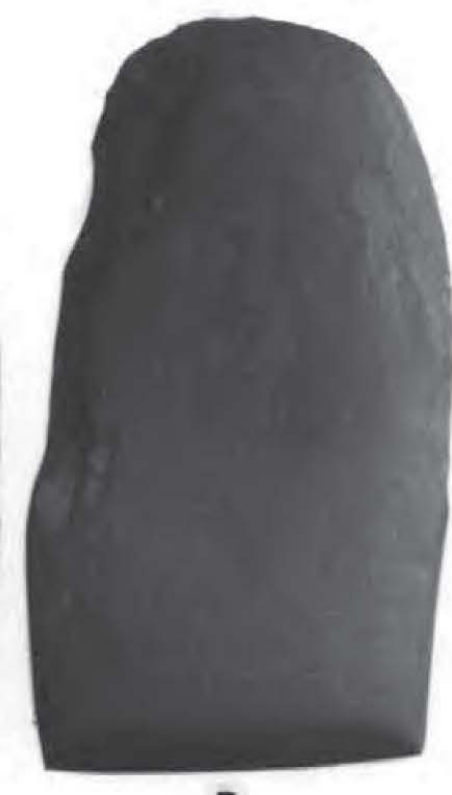

R

Figure 4. Artifacts from Village and Mortuary Contexts: a, clay earplug (square 5L); b, clay earplug (square 2G); c, Taylor Engraved rim (square 3H); d, Coles Creek Incised (square 5E); Bowie Engraved (square 4D); f-j, tools from Feature 69, including notching tool (f); celts ( $\mathrm{g}$ and $\mathrm{j})$; hammerstone $(\mathrm{h})$; and possible fleshing tool $(\mathrm{i}) ; \mathrm{k}$, fingernail punctated rim (square $1 \mathrm{H}) ; 1$, pinched rim (square $5 \mathrm{E}$ ); $\mathrm{m}$, fingernail punctated (square $1 \mathrm{~F}$ ); $\mathrm{n}$, drilled pottery disk (square 4F); o, mano (square $1 \mathrm{H}$ ); p, engraved adze-like tool (Burial 38); q, slate celt (Burial 18); r, siltstone celt (Burial 7). Note: items c-e, k-o reduced two-thirds. 
Head Orientation:West-Northwest

Grave Goods: Eight Clark Engraved bowls, including three small examples found left of the skull and between the knees and lower legs, and a typical sized form at the left elbow; three Clark Engraved bowls with rim lugs (near the rear of the skull, in the southwest corner of the grave, and in the southeast grave corner), and a fourth with rim castellations in the southwest corner of the grave; an Avery Engraved bowl near the right shoulder (see Figure 11c), another by the left shoulder, and a large Avery Engraved bottle on the feet; one large Emory Punctated-Incised jar (with rim castellations and lugs) near the left femur (see Figure 7i), and a second in the southeast corner of the grave; a clay pipe by the left shoulder (see Figure 16e); and three Scallorn sattler arrowpoints, two near the left knee and the third by the right foot (Figure $5 b$ ).

\section{Burial 9}

Age:Child

Provenience:5aa

Depth: $102 \mathrm{~cm}$

Grave Size: 51 x $154 \mathrm{~cm}$

Head Orientation:West-Northwest

Grave Goods:Small, plain bottle by the back of the skull; a small, plain V-shaped bowl near the right side of skull, along with a small red bowl with two lug handles (see Figure $15 \mathrm{e})$; small, plain castellated jar near the left shoulder and a small V-shaped bowl by the left arm; and an Emory Punctated-Incised jar near the right arm.

Burials 10 and 11

Age: Child and Adult; the child lay on the left arm of the adult

Provenience:5aa

Depth: $159 \mathrm{~cm}$

Grave Size: 108 x $225 \mathrm{~cm}$

Head Orientation:West-Northwest

Grave Goods:Three Emory Punctated-Incised vessels (two jars and one bowl); the miniature bowl was by the left knee of the adult, while the jars were behind the skull and near the left elbow of the child. The jar by the skull contained a small turtle carapace with small pebbles in it; the vessel rested on a group of articulated fish bones from three small blue gill. Other vessels included an Avery Engraved bottle by the left rear side of the adult skull; a small, plain red carinated bowl by the child's left shoulder (see Figure 9a) and another by the left elbow; a small, red conical bowl and a small, plain shallow bowl at the right hand of the adult; and a red pottery sherd (a possible cover) lay near the right foot of the adult.

\section{Burial 12}

Age:Adult

Provenience:5bb, $5 c c$

Depth: $115 \mathrm{~cm}$

Grave Size: 113 x $276 \mathrm{~cm}$

Head Orientation:West

Grave Goods: Eight arrow points, five next to the right tibia and the others by the left tibia (and pointing east). They include one Washita peno and seven Scallorn sattler forms (see Figure 5d). Ceramic items consist of a clay pipe near the left mandible; three Avery Engraved bowls (a large form at the head of the grave [see Figure 11d], small bowl between the femurs, and another large bowl near the right foot) and an Avery Engraved bottle near the upper left side of the skull; five Clark Engraved bowls (one near the left shoulder, another near the skull, and locational information is lacking on three poorly-fired bowls that were not apparently recoverable [Editor's Note]); a large Bowie Engraved 

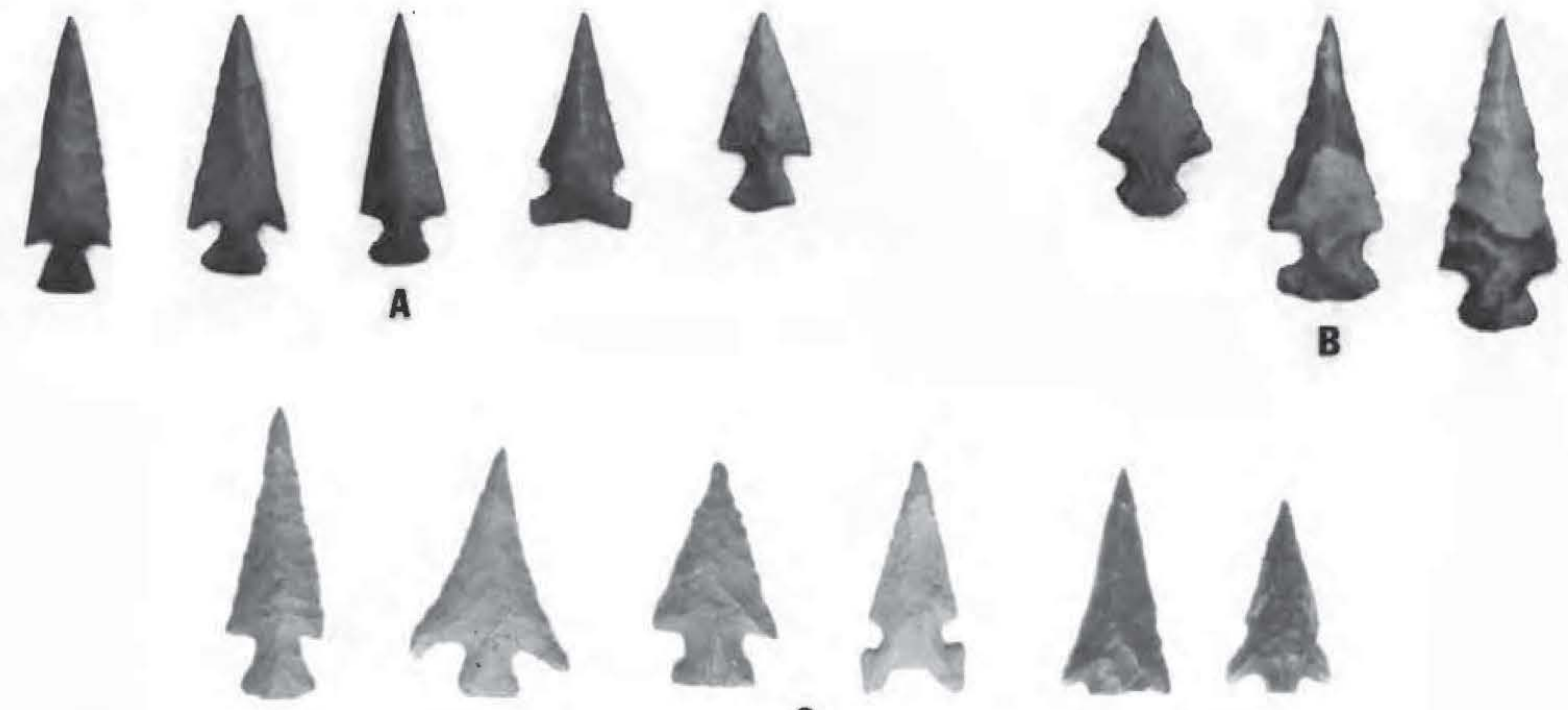

C
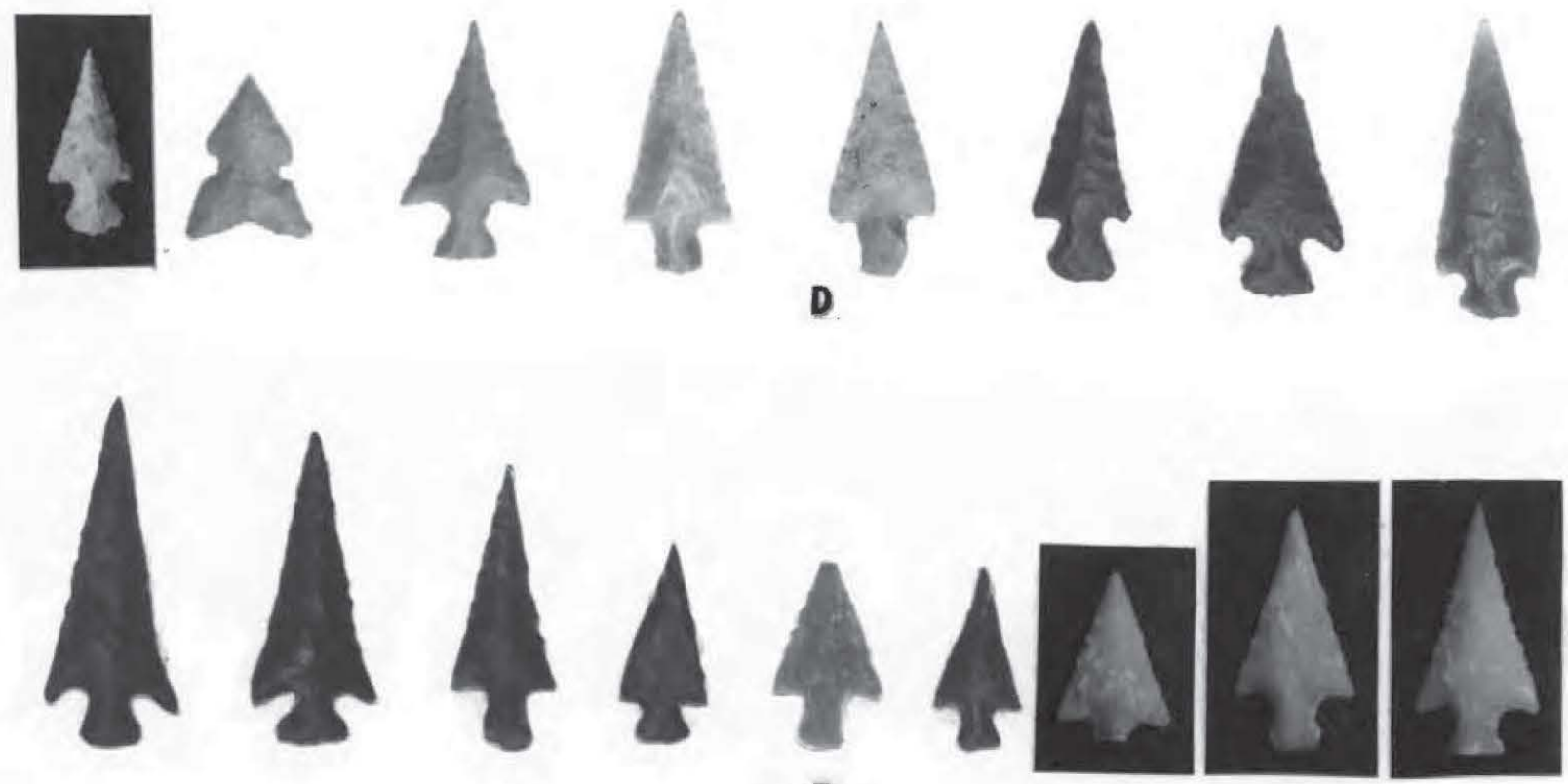

E
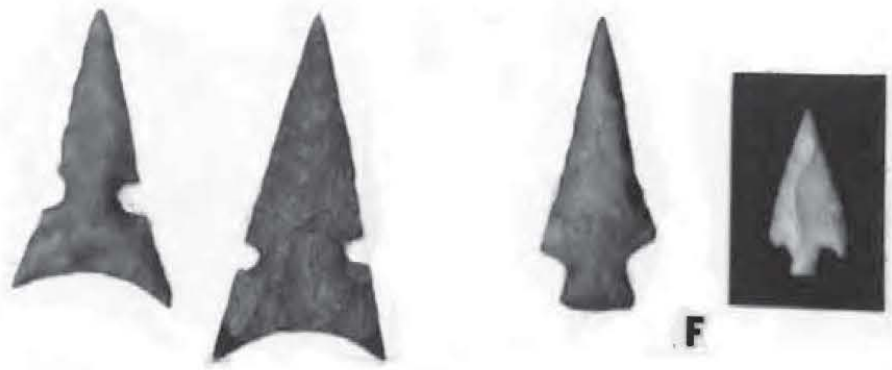

Figure 5. Arrow points with Early McCurtain phase burials: a, corner-notched and sidenotched forms in Burial 3; b, corner-notched examples, Burial 8; c, corner-notched and side-notched arrowpoints in Burial 6; d, Burial 12; e, Burial 15; f, Burial 7. 
conical bowl (see Figure 10d) against the grave wall left of the skull, with a small Emory Punctated-Incised jar under it; a second Emory jar was near the left tibia (see Figure 7c). A sherd "pot cover" was lying on the left hand of Burial 12.

\section{Burial 13}

Age:Adult

Provenience:6aa, $6 \mathrm{bb}$

Depth: $138 \mathrm{~cm}$

Grave Size:95 x $210 \mathrm{~cm}$; part of the northwestern wall intersected Burial 14

Head Orientation:West-Northwest

Grave Goods:Emory Punctated-Incised jar near the left shoulder; Nash Neck-Banded jar resting on the right humerus; three plain bowls (one on the left arm, a second on the right elbow and forearm, and the third resting on the left femur near the knee); and near the right shoulder, a bottle with three large painted red dots on the sides and a red painted neck (see Figure $8 \mathrm{~g}$ ).

\section{Burial 14}

Age:Adult

Provenience:6aa

Depth: $138 \mathrm{~cm}$

Grave Size: 108 x $197 \mathrm{~cm}$

Head Orientation:East-Southeast

Grave Goods:A large plain bottle near the right humerus, and three poorly fired plain bowls near the right arm; a red pottery sherd "pot cover" was also found near the vessels, along with a deer jaw pick.

Burial 15

Age:Adult

Provenience:7bb, 7cc

Depth: $133 \mathrm{~cm}$

Grave Size: 108 x $251 \mathrm{~cm}$

Head Orientation:West

Grave Goods: Nine Scallorn sattler corner-notched arrowpoints near the right femur and right hand; all appear to have been made by the same individual (see Figure 5e); antler knapping tools and a clay pipe by the upper end of the right humerus; four Avery Engraved bowls (on the left wrist, near the left knee, by the left hand, and on the right pelvis) and an Avery Engraved bottle by the left side of the skull. The Avery Engraved bowl near the left knee (see Figure I0b) contained red, green, and gray clay for pigments, a sandstone slab, and some chert flakes. Two Clark Engraved bowls were also included as grave goods, one found by the right side of the skull (see Figure 13f) while the other (which contained green clay) was placed near the right hand; a poorly preserved plain jar was resting on the left wrist.

\section{Burial 16}

Age:Adult

Provenience:7cc

Depth: $133 \mathrm{~cm}$

Grave Size: $92 \times 256 \mathrm{~cm}$

Head Orientation:West

Grave Goods:Eight ceramic vessels, five placed from head to pelvis in a row along the right side. These five included (in order from head to pelvis) a unique carinated bowl with neck-banding on the rim and an Avery Engraved design on the shoulders (see Figure 9b), a Nash Neck-Banded jar, a plain red conical bowl of the Simms form, a possible McKinney Plain jar (but with slash-like punctates on the collar), and a small Avery Engraved conical 
bowl. The other three vessels include a Clark Engraved bowl resting on the right humerus; an Avery Engraved bottle by the left elbow; and a plain Simms form bowl near the left side of the skull.

\section{Burial 17}

Age:Adult

Provenience: $8 \mathrm{bb}$

Depth: $118 \mathrm{~cm}$

Grave Size: 97 x $210 \mathrm{~cm}$

Head Orientation:West-Northwest

Grave Goods:A small effigy bowl near the right shoulder (see Figure 15f); an Emory Punctated-Incised jar by the right elbow, with green clay pigment between it and the effigy bowl; two plain Simms form conical bowls, one by the left hand and the other by the left elbow; and a small plain globular bowl by the left humerus.

\section{Burial 18}

Age:Adult

Provenience:7aa

Depth: $138 \mathrm{~cm}$

Grave Size: 36 x $236 \mathrm{~cm}$

Head Orientation:East-Southeast

Grave Goods:Five ceramic vessels, including a Nash Neck-Banded jar by the right hand, a large Avery Engraved red bowl against the grave wall beyond the left arm (see Figure 11f), a Avery Engraved bottle by the left elbow, a plain bowl near the right femur, and a Clark Engraved bowl by the left knee. A small celt (see Figure 4q) was placed near the left hand and pelvis, while a clay pipe (see Figure 16c) rested against the inner side of the right femur. A few chert flakes were by the left hand.

Burial 19

Age:Adult

Provenience:8aa

Depth: $113 \mathrm{~cm}$

Grave Size:97 x $195 \mathrm{~cm}$

Head Orientation:West-Southwest

Grave Goods:Four ceramic vessels were placed with Burial 19, along with a piece of a deer leg bone (by the right elbow). A small, plain jar was near the right shoulder, while a Vshaped bowl and a Clark Engraved bowl were by the right lower legs. A Nash NeckBanded jar was found near the left forearm.

\section{Burial 20}

Age:Adult

Provenience:7B

Depth: $133 \mathrm{~cm}$

Grave Size: 118 x $200 \mathrm{~cm}$

Head Orientation:West-Northwest

Grave Goods: A deer mandible pick leaning against the right side of the skull; an Avery Engraved bottle and two Clark Engraved bowls (one with green clay, and one on top of the other) (see Figure 13c, g) by the left side of the skull; a plain bowl and a chunk of red ochre near the right hand; and a McKinney Plain jar by the right knee.

\section{Burial 21}

Age:Adult

Provenience: $3 \mathrm{~A}$

Depth: $15-30 \mathrm{~cm}$ 
Grave Size:Undetermined; buried shallowly in a house floor, with the plow having removed part of the skull and portions of the vessels

Head Orientation:West-Southwest

Grave Goods:Four ceramic vessels, including a large Avery Engraved bottle near the right shoulder and skull, two Clark Engraved bowls (one by the left elbow and the other near the left knee), and a Nash Neck-Banded jar above the right shoulder. A Scallorn arrow point was resting by the right shoulder

\section{Burial 22}

Age:Adult

Provenience:7D

Depth: $115 \mathrm{~cm}$

Grave Size: 67 x $208 \mathrm{~cm}$

Head Orientation:Southwest

Grave Goods:An Avery Engraved bottle was along the right side of the skull (see Figure $8 \mathrm{e}$ ), and a bowl was by the right tibia (see Figure 13h); a large Avery Engraved "pot cover" (made from a conical bowl) was near the left foot. Another "pot cover" by the right foot was from a large Emory Punctated-Incised sherd, while a complete Emory jar was at the left elbow. A deer jar pick and a lump of green clay pigment were next to this jar. Two Nash Neck-Banded jars were among the grave goods, one by the left shoulder and the other by the right elbow.

\section{Burial 23}

Age:Child

Provenience:7D

Depth: $108 \mathrm{~cm}$

Grave Size: 62 x $185 \mathrm{~cm}$

Head Orientation:West

Grave Goods: Among the four vessels with Burial 23 were a small, plain conical bowl placed by the left side of the head; a Simms Engraved bowl near the right femur; and two Avery Engraved bowls: one by the right arm and the other by the right foot.

\section{Burial 24}

Age:Adult

Provenience:5C

Depth: $108 \mathrm{~cm}$

Grave Size: 85 x $200 \mathrm{~cm}$

Head Orientation:Southwest

Grave Goods:Base of a ceramic jar (reworked into a bowl) near the left knee; a red, conical Avery Engraved bowl by the right elbow, along with a deer mandible pick.

Burial 25

Age:Adult

Provenience:6D

Depth: $133 \mathrm{~cm}$

Grave Size: 74 x $246 \mathrm{~cm}$

Head Orientation:West

Grave Goods:Ceramic vessels include a red, conical Avery Engraved bowl by the right side of the skull (see Figure 10e); a carinated Avery Engraved bowl resting on the right forearm, and another at the right hand (the hand bones having fallen in it); a turtle effigy bottle behind the skull (see Figure 8c); one Nash Neck-Banded jar against the grave pit wall and near the left shoulder, and another resting on the left knee (see Figure 7e); and a clay pipe against the left shoulder. A cluster of stone and bone artifacts were found against the right knee, and their integrity suggests they may have been within a pouch:four deer antler 
knapping tools; two deer ulna knapping tools and a deer ulna awl; a bone splinter awl; a clay pipe; a ball of hematite, a small piece of sandstone, as well as a piece of highly eroded limestone; a roughly shaped celt; and a group of chert flakes.

\section{Burial 26}

Age:Adult

Provenience:6F

Depth: $128 \mathrm{~cm}$

Grave Size: 92 × $246 \mathrm{~cm}$

Head Orientation:West-Southwest

Grave Goods:A large number of stone and ceramic artifacts were placed with Burial 25. Near the femurs were 16 Maud arrow points (nine by the left femur and seven by the right), all pointing east (Figure 6b). A Taylor Engraved bottle lay against the left side of the skull, and two Avery Engraved conical bowls were near the left and right arms, and a third was at the foot of the grave (see Figure 12c); all had identical decorations and may have been made by the same person. A Nash Neck-Banded jar was near the left elbow, a Simms Engraved bowl by the left hand, and an Avery Engraved bowl by the left knee. A bowl made from the bottom of a broken jar was by the left ankle. Finally, many large fragments from a very large Nash Neck-Banded jar were in the grave fill.

\section{Burial 27}

Age:Adult

Provenience: $6 \mathrm{G}$

Depth: $128 \mathrm{~cm}$

Grave Size: $69 \times 215 \mathrm{~cm}$

Head Orientation:West-Southwest

Grave Goods:They consisted of a deer mandible pick laying against the left side of the skull, and three ceramic vessels. By the right shoulder was the bottom of a red, conical bowl; an Avery Engraved conical bowl (see Figure 12b) was near the left humerus; and a Simms Engraved shallow bowl (see Figure 13i) was by the right hand (the hand of the individual was in the bowl).

\section{Burial 28}

Age:Adult

Provenience: $6 \mathrm{H}$

Depth: $126 \mathrm{~cm}$

Grave Size: 62 x $188 \mathrm{~cm}$

Head Orientation:West-Northwest

Grave Goods:Three ceramic vessels, the first the base of a jar reworked into a bowl; it was near the right shoulder. A large, plain red-slipped bowl of the Simms form was by the left pelvis (see Figure 10f), and a small, globular Nash Neck-Banded jar was near the left knee.

\section{Burial 29}

Age:Adult

Provenience:4D

Depth: $133 \mathrm{~cm}$

Grave Size: 67 x $184 \mathrm{~cm}$

Head Orientation:West-Southwest

Grave Goods: A red conical Avery Engraved bowl (see Figure 12a) near the right forearm; a jar reworked into a bowl by the right foot; and a pottery "cover" near one of the elbows. A deer mandible pick lay under the "pot cover." 

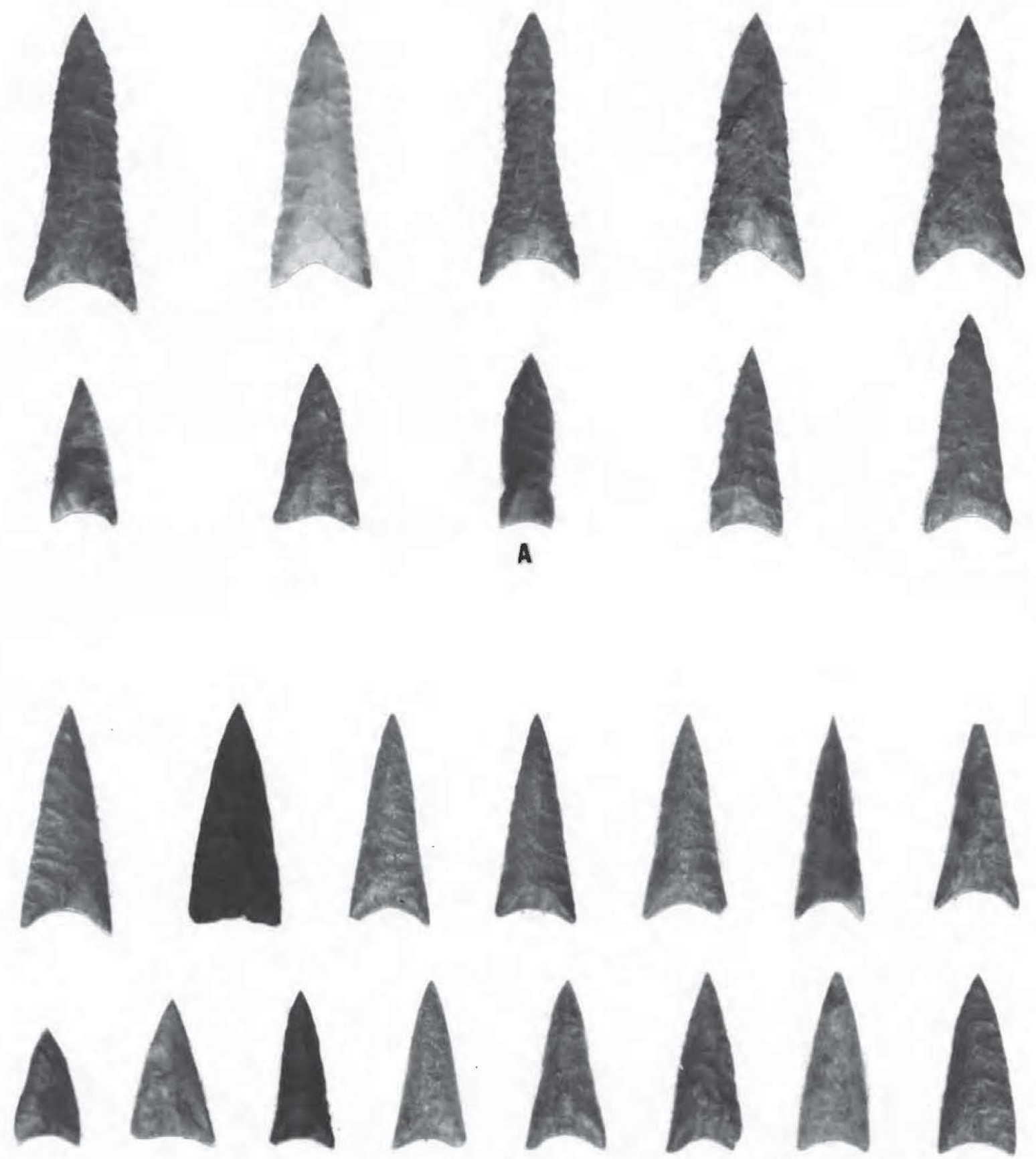

B

Figure 6. Arrowpoints with the Late McCurtain phase burials: a, Talco, Maud, and sidenotched Maud points with Burial 31; b, Maud points in Burial 26. 


\section{Burial 30 \\ Age:Child \\ Provenience: $4 \mathrm{E}$ \\ Depth:69 cm \\ Grave Size:Undetermined (no preserved skeletal remains) \\ Head Orientation:West (?) \\ Grave Goods:A bowl made from the body of a Hodges Engraved bottle; the edge of the rim had been cut evenly and ground smooth. A plain, miniature jar with four rim tabs was also included with the grave.}

\section{Burial 31}

Age:Adult

Provenience: $4 \mathrm{E}, 5 \mathrm{E}, 5 \mathrm{~F}$

Depth: $120 \mathrm{~cm}$

Grave Size: $90 \times 200 \mathrm{~cm}$

Head Orientation:West-Southwest

Grave Goods:A wide variety of associated artifacts were present with Burial 31. Ten arrow points (six Talco, three Maud, and one side-notched Maud) were found in a group (see Figure 6a) by the left side of the skull, along with a clay pipe with a Taylor Engraved motif by the left jaw (see Figure 16a). Near the right shoulder was a Gary point, a Gary preform, a sandstone slab abrader, and a quartz crystal. Four ceramic vessels were placed near the right shoulder and humerus (Avery Engraved bowl), near the left hand (red, conical Avery Engraved bowl), at the feet (Nash Neck-Banded jar), and by the right pelvis (Simms Engraved bowl).

Burial 32

Age:Infant

Provenience:5F

Depth:43 cm

Grave Size:Undetermined; few preserved human remains.

Head Orientation:West-Northwest (?)

Grave Goods: None. The infant was probably buried in the floor of a house.

\section{Burial 33}

Age:Adult

Provenience:5G

Depth: $113 \mathrm{~cm}$

Grave Size: $69 \times 215 \mathrm{~cm}$

Head Orientation:West-Northwest

Grave Goods: These consisted of two Avery Engraved vessels (red, conical bowl by the left side of the skull and bottle by the right forearm [see Figure 8d]), a Simms Engraved bowl between the legs but above the knees, and a Nash Neck-Banded jar near the right rear of the skull. Sherds from another bottle were about $30 \mathrm{~cm}$ above the feet in the grave fill.

\section{Burial 34}

Age:Adult

Provenience: $5 \mathrm{H}$

Depth: $106 \mathrm{~cm}$

Grave Size:51 x $179 \mathrm{~cm}$

Head Orientation:East-Northeast

Grave Goods:A Simms Engraved bowl was by the right pelvis; the individual's right hand lay in the bowl. The bowl also contained the bones of a small bird similar to a sparrow or finch (Paul Parmalee, personal communication). Near the right humerus was a miniature, 
plain bottle, while the base of a large bottle made into a bowl was found above the head of the grave but only slightly below the plow zone.

\section{Burial 35 \\ Age:Adult \\ Provenience:4G \\ Depth: $110 \mathrm{~cm}$ \\ Grave Size: 69 × $200 \mathrm{~cm}$ \\ Head Orientation:East-Northeast; the lower legs of this individual were missing. \\ Grave Goods:Two Avery Engraved bowls were with Burial 35. One was near the left hand, and the other lay against the left hand, and had the hand bones in it. \\ Burial 36 \\ Age:Adult \\ Provenience: $2 \mathrm{~F}$ \\ Depth: $118 \mathrm{~cm}$ \\ Grave Size: 77 x $215 \mathrm{~cm}$ \\ Head Orientation:East-Northeast \\ Grave Goods:Eleven arrow points (10 Maud and one Bassett) were found in a group by the right foot; a possible Scallorn and a Gary point were recovered deep in the grave fill. Ceramic vessels included a Keno Trailed bottle (see Figure 8a) near the right pelvis; a red, conical Taylor Engraved bowl near the right humerus; and two Emory Punctated-Incised jars. One of the jars was near the right knee (see Figure $16 \mathrm{~g}$ ), and the other (with fleur-de- lis decorative handles) near the skull (Figure 7h).}

\section{Burial 37}

Age:Adult

Provenience:1D, 2D

Depth:95 cm

Grave Size: 59 x $174 \mathrm{~cm}$

Head Orientation:West-Southwest

Grave Goods:Associated artifacts included a deer mandible pick by the right knee, and a shallow Simms Engraved bowl by the right pelvis.

\section{Burial 38}

Age:Adult

Provenience: IF

Depth: $120 \mathrm{~cm}$

Grave Size: 67 x $215 \mathrm{~cm}$

Head Orientation:West-Southwest

Grave Goods:A deer mandible pick rested in the stomach area, and a slate adze (see Figure $4 \mathrm{p}$ ) was near the right hand. There were five ceramic vessels with this individual, including a Taylor Engraved bowl containing the bones of a gray squirrel (vessel's location within grave is unknown [Editor's note]), two Keno Trailed bottles (by the right knee and near the right side of the head [Figure 8b]), a small, red jar by the second Keno Trailed bottle, and an Emory Punctated-Incised jar near the left cheek. 


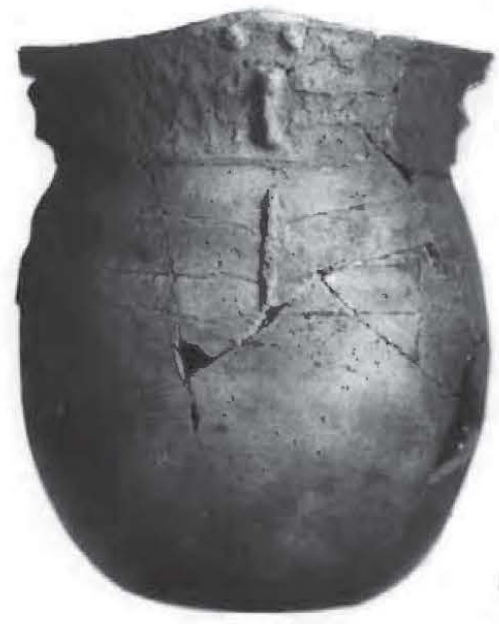

A

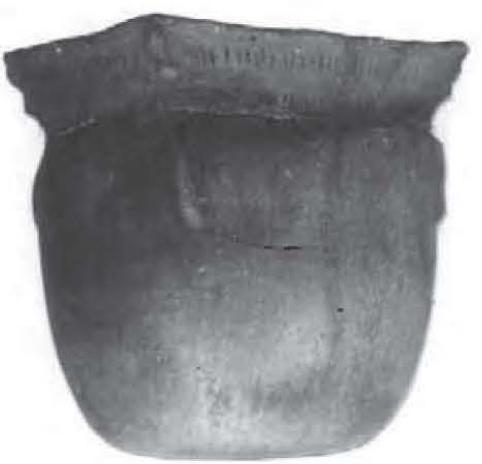

D

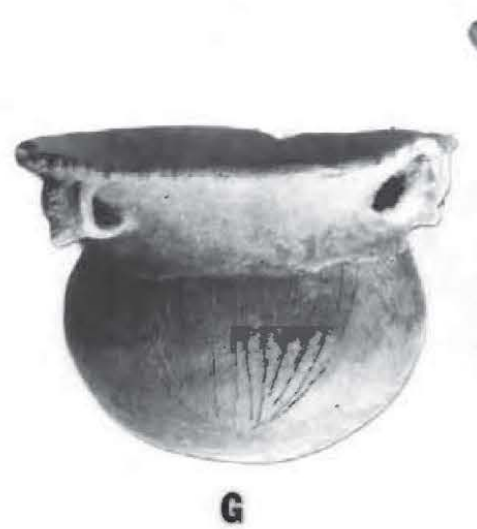

G

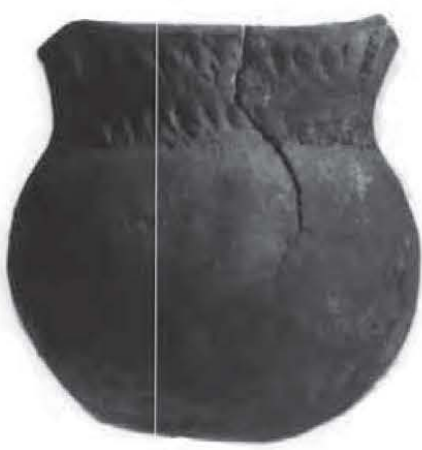

B

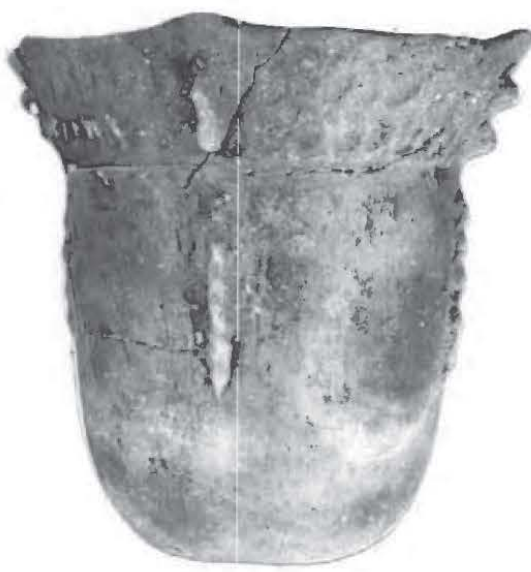

E

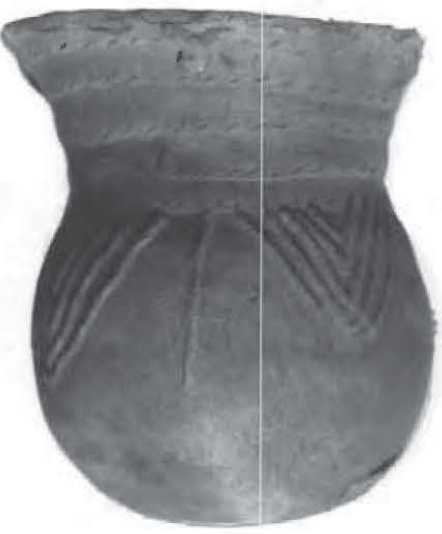

н
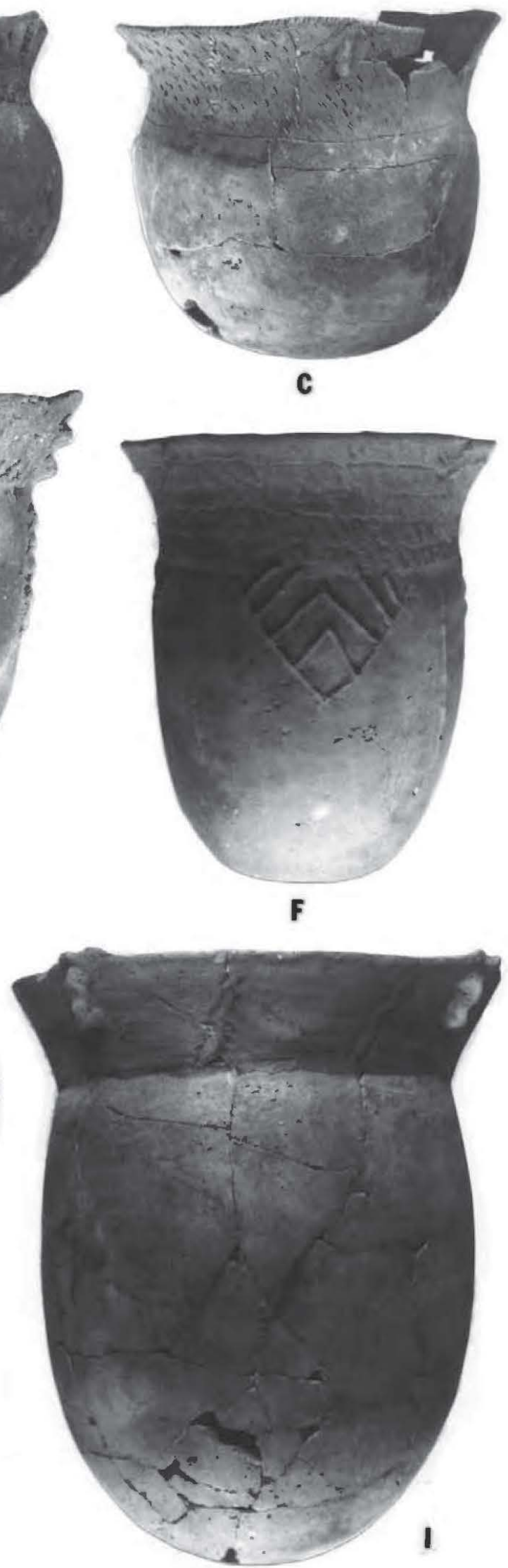

Figure 7. Jar Forms:a-c, g, i, early McCurtain phase; d-f, h, late McCurtain phase. a, Burial 21; b-d, h, Emory Punctated-Incised, Burial 12, 8, mound, and Burial 36; e-f, Nash Neck-Banded, Burial 25 and the mound; g, Burial 39; i, Burial 8. 

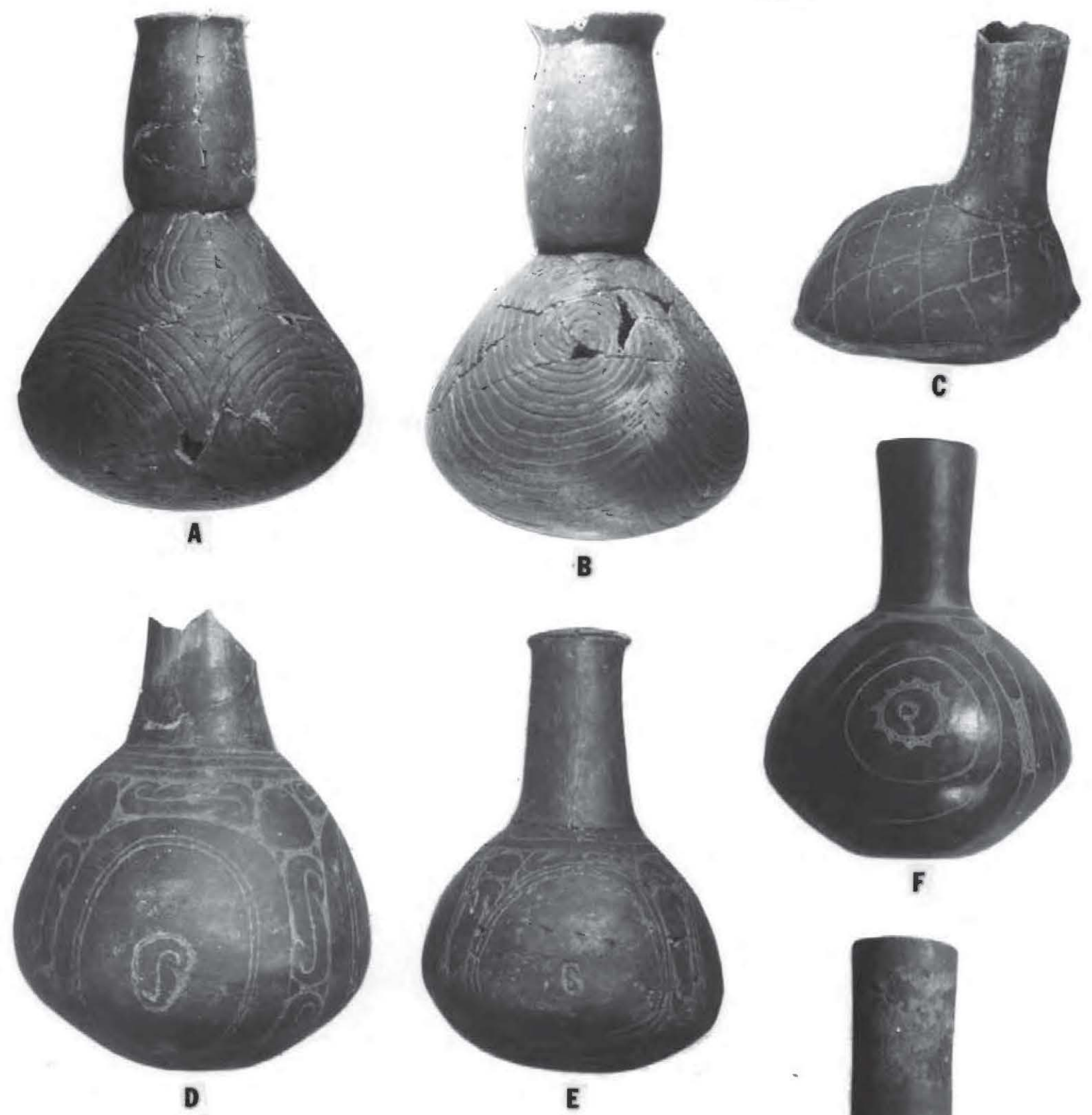

F

$\mathbf{E}$

Figure 8. Bottles: a-b, Keno Trailed, Burials 36 and 38; c, turtle effigy, Burial 25; d-f, Avery Engraved, Burials 33, 22, and mound; g, painted bottle, Burial 13. 


\begin{abstract}
Burial 39
Age:Child

Provenience:4E

Depth:77 cm

Grave Size: 49 x $98 \mathrm{~cm}$

Head Orientation:North-Northeast

Grave Goods:One small, globular jar with strap handles and a pinched decoration on the shoulders (see Figure 7g).

Two other possible burials were recorded in the excavations, Feature 21 (Squares $1 \mathrm{~A}$ and 1B) and Feature 62 (Square 5H) (See Figure 2). Feature 21 was probably a child's grave, although no bones remained in the pit. The pit was ca. $44 \mathrm{~cm}$ deep. Feature 62 consisted of the bottom of a ceramic bottle; the upper part had been plowed away. It may be associated with Burial 34 since it is near the eastern end of the grave.
\end{abstract}

\title{
Features
}

A variety of other types of McCurtain phase features were excavated at the Rowland Clark site. These were recognized after the plow zone was cleared away. Although many post molds were found, no specific house patterns could be defined; the numbers of post molds suggest an intensive occupation during the McCurtain phase in the excavation area. Included in the 67 other features were pits (ranging from postmolds to smudge pits) and hearths, as well as one dog burial.

The most interesting features were the smudge pits in which corn cobs, wood, and pine cones were burned to create a smudge or smoke for curing skins. Smudge pits were commonly found in groups in the area where houses had apparently been constructed. These pits were generally $26-47 \mathrm{~cm}$ in diameter and about $30-47 \mathrm{~cm}$ in depth. Corn cobs were used most often in the smudge pits (see also Appendix 1 by Blake, this volume), but wood and pine cones were used on occasion independently or mixed with other plant materials. In some cases postholes were reutilized as smudge pits and ash pits; previous excavations on the Red River had not previously documented this type of feature re-use. Information on the 28 smudge pits is provided in Table 1.

Table 1. Smudge Pits.

Feature No. Location Size $(\mathrm{cm}) \quad \operatorname{Depth}(\mathrm{cm}) \quad$ Comments

\begin{tabular}{|c|c|c|c|c|}
\hline 2 & Sq. $5 b b$ & 31 & 39 & Contained charcoal \\
\hline 9 & Sq. $6 \mathrm{~A}$ & 16 & 73 & $\begin{array}{l}\text { Smudge pit within posthole } \\
\text { Contained charred corncobs }\end{array}$ \\
\hline 10 & Sq. 4aa & 26 & 52 & $\begin{array}{l}\text { Contained a large bowl sherd } \\
\text { on pit bottom; group of } \\
\text { corncobs rested on it }\end{array}$ \\
\hline 11 & Sq. $4 \mathrm{~A}$ & 34 & 68 & Contained charred materials \\
\hline 12 & Sq. $4 \mathrm{~A}$ & 31 & 39 & Contained corncobs \\
\hline 14 & Sq. $4 \mathrm{~A}$ & 36 & 39 & Contained charred wood \\
\hline
\end{tabular}


Table 1, cont.

\begin{tabular}{|c|c|c|c|c|}
\hline 15 & Sq. $4 A$ & 31 & 44 & Contained corncobs \\
\hline 19 & Sq. $2 A$ & 16 & 73 & $\begin{array}{l}\text { Smudge pit in posthole; } \\
\text { contained corncobs }\end{array}$ \\
\hline 20 & Sq. $2 \mathrm{~A}$ & 16 & 73 & $\begin{array}{l}\text { Smudge pit in posthole; } \\
\text { contained corncobs }\end{array}$ \\
\hline 24 & Sq. 3B & 47 & 65 & Contained corncobs \\
\hline 25 & Sq. 3B & 31 & 52 & Contained corncobs \\
\hline 26 & Sq. 3C & 39 & 55 & $\begin{array}{l}\text { Contained corncobs and } \\
\text { charcoal }\end{array}$ \\
\hline 27 & Sq. 3B & 26 & 78 & Contained corncobs \\
\hline 28 & Sq. 3B & 31 & 81 & Contained charcoal \\
\hline 30 & Sq. 3B & 31 & 78 & Contained corncobs \\
\hline 39 & Sq. $6 \mathrm{C}$ & 39 & 47 & Contained charcoal \\
\hline 43 & Sq. $4 \mathrm{C}$ & 31 & 83 & $\begin{array}{l}\text { Smudge pit in posthole; } \\
\text { contained corncobs and } \\
\text { charred pine cones }\end{array}$ \\
\hline 47 & Sq. 7D & 26 & 47 & Contained corncobs \\
\hline 48 & Sq. 6D & 31 & 63 & Contained corncobs \\
\hline 49 & Sq. 5D & 31 & 60 & Contained charcoal \\
\hline 50 & Sq. 5D & 26 & 63 & Contained charcoal \\
\hline 51 & Sq. 5D & 31 & 57 & Contained charcoal \\
\hline 52 & Sq. 4D & 31 & 63 & Contained charcoal \\
\hline 56 & Sq. $4 \mathrm{E}$ & 26 & 83 & $\begin{array}{l}\text { Contained corncobs; possible } \\
\text { posthole converted into a } \\
\text { smudge pit }\end{array}$ \\
\hline 58 & Sq. $3 F$ & 31 & 49 & Contained corncobs \\
\hline 60 & Sq. 5G & 31 & 47 & Contained corncobs \\
\hline 61 & Sq. $5 \mathrm{H}$ & 26 & 47 & Contained corncobs \\
\hline 64 & Sq. $4 \mathrm{H}$ & 36 & 57 & Contained corncobs \\
\hline
\end{tabular}


Smudge pits are thought to have been used for the smoke-curing of skins (Binford 1967), although Munson (1969) suggests that the smoke from them might have been used to smudge pottery.

Two kinds of hearths were noted among the 21 hearths at the Rowland Clark site. The first kind $(\mathrm{N}=6)$ was found on house floors and had flat, burned areas with several $\mathrm{cm}$ of ash still lying on them. The other kind of hearth $(\mathrm{N}=15)$ consisted of heavily burned floors in pits; the pit fills contained layers of ash and scattered charcoal. These hearths in pits were usually between $1-1.25 \mathrm{~m}$ in diameter. Table 2 summarizes information on the two kinds of Rowland Clark hearths.

Table 2. Hearths

\begin{tabular}{|c|c|c|c|c|}
\hline Feature No. & Location & Size $(\mathrm{cm})$ & Depth $(\mathrm{cm})$ & Comments \\
\hline 3 & Sq. $6 \mathrm{bb}$ & 88 & 39 & $\begin{array}{l}\text { Contained wood ash and } \\
\text { charcoal flecks }\end{array}$ \\
\hline 4 & Sq. $5 \mathrm{~A}$ & 83 & 65 & $\begin{array}{l}\text { Rounded, burned bottom } \\
\text { covered with ashes }\end{array}$ \\
\hline 5 & Sq. $5 \mathrm{~A}$ & 83 & 65 & $\begin{array}{l}\text { Flat bottom with } 5 \mathrm{~cm} \text { of ash } \\
\text { on it; Feature } 9 \text { bisected NE } \\
\text { edge of hearth }\end{array}$ \\
\hline 6 & Sq. $5 \mathrm{~A}$ & 83 & 65 & $\begin{array}{l}\text { Rounded, burned bottom } \\
\text { covered with ashes }\end{array}$ \\
\hline 7 & Sq. 7A & 117 & 68 & $\begin{array}{l}\text { Fire-reddened and rounded } \\
\text { bottom; contained ash and } \\
\text { charcoal }\end{array}$ \\
\hline 8 & Sq. 7A & 117 & 68 & $\begin{array}{l}\text { Feature } 7 \text { overlapped this } \\
\text { hearth }\end{array}$ \\
\hline 16 & Sq. $3 \mathrm{~A}$ & 109 & 52 & Flat, fire-reddened bottom \\
\hline 17 & Sq. $3 \mathrm{~A}$ & 114 & 47 & $\begin{array}{l}\text { Flat-bottomed with } 10 \mathrm{~cm} \text { of } \\
\text { wood ash }\end{array}$ \\
\hline 18 & Sq. 3A & 114 & ND & $\begin{array}{l}\text { Flat-bottomed with charred } \\
\text { corn kernels, charrcd acorns, } \\
\text { charred hickory nutshells, and } \\
\text { persimmon seeds }\end{array}$ \\
\hline 29 & Sq. 3, 4B & 47 & 31 & Contained wood ash \\
\hline 36 & Sq. $7 B$ & 114 & 57 & $\begin{array}{l}\text { Flat-bottomed with charcoal; } \\
\text { Burial } 20 \text { cuts through it }\end{array}$ \\
\hline 37 & Sq. $7 \mathrm{C}$ & 88 & 57 & Contained wood ash \\
\hline
\end{tabular}


Table 2, cont.

\begin{tabular}{|c|c|c|c|c|}
\hline 38 & Sq. $6 \mathrm{C}$ & 52 & $\mathrm{ND}$ & $\begin{array}{l}\text { Flat hearth with wood ash. } \\
\text { Found just below plow zone }\end{array}$ \\
\hline 40 & Sq. $5 \mathrm{C}$ & 114 & 63 & $\begin{array}{l}\text { Flat-bottomed with } 21 \mathrm{~cm} \text { of } \\
\text { ash }\end{array}$ \\
\hline 41 & Sq. $6 \mathrm{C}$ & 52 & 63 & Contained wood ash \\
\hline 42 & Sq. $4 \mathrm{C}$ & 99 & 52 & Contained ashes \\
\hline 44 & Sq. $3 \mathrm{C}$ & 104 & 42 & $\begin{array}{l}\text { Rounded bottom with } \\
\text { charcoal }\end{array}$ \\
\hline 45 & Sq. $3 \mathrm{C}$ & 78 & 52 & Contained wood ash \\
\hline 46 & Sq. $1 \mathrm{C}$ & 52 & 47 & Contained wood ash \\
\hline 55 & Sq. $6 \mathrm{E}$ & 78 & 63 & $\begin{array}{l}\text { Contained charcoal and } \\
\text { wood ash }\end{array}$ \\
\hline 68 & Sq. $1 \mathrm{H}$ & 47 & ND & $\begin{array}{l}\text { Flat hearth with wood ash } \\
\text { and soil burned to depth of } \\
8 \mathrm{~cm} \text {; exposed just under } \\
\text { plow zone }\end{array}$ \\
\hline
\end{tabular}

In addition to the smudge pits, there were eleven large and irregular-shaped pits, five ash pits, and one cache pit. These pits are similar to those at the Roden site in McCurtain County, Oklahoma (Perino 1981). Characteristics of these pits are summarized in Table 3.

Table 3. Pits from the Rowland Clark Site

\begin{tabular}{lllll}
\hline Pit No. & Location & Size $(\mathrm{cm})$ & Depth $(\mathrm{cm})$ & Comments \\
\hline 1 & Sq. 4cc & 99 & 94 & $\begin{array}{l}\text { No evidence of use; probable } \\
\text { storage pit }\end{array}$ \\
13 & Sq. 4A & 78 & 47 & Contained mixed fill \\
22 & Sq. 1B & 26 & 52 & Ash pit \\
23 & Sq. 2B/C & 63 & 83 & Contained mixed fill \\
31 & Sq. 4B & 26 & 78 & Ash pit in posthole \\
32 & Sq. 4B & 26 & 78 & Ash pit in posthole
\end{tabular}


Table 3, cont.

\begin{tabular}{|c|c|c|c|c|}
\hline 33 & Sq. $4 B$ & 26 & 78 & Ash pit in posthole \\
\hline 34 & Sq. $4 B$ & 57 & 47 & $\begin{array}{l}\text { Contained charred corn cobs } \\
\text { and wood ash }\end{array}$ \\
\hline 35 & Sq. 4B & 26 & 73 & Ash pit in posthole \\
\hline 53 & Sq. 3D & 187 & 52 & Contained mixed fill \\
\hline 54 & Sq. 3D & 187 & 26 & $\begin{array}{l}\text { Contained red and black clay } \\
\text { levels }\end{array}$ \\
\hline 57 & Sq. 3E & 47 & 63 & Contained charcoal flecks \\
\hline 63 & Sq. $4 \mathrm{G}$ & 47 & 52 & Contained mixed fill \\
\hline 65 & Sq. $2 \mathrm{H}$ & 94 & 52 & Contained mixed fill \\
\hline 66 & Sq. $2 \mathrm{H}$ & 125 & 78 & Contained mixed fill \\
\hline 67 & Sq. $2 \mathrm{H}$ & 52 & 63 & $\begin{array}{l}\text { Cut across Feature } 66 . \text { The } \\
\text { bottom of a ceramic jar was } \\
\text { in the fill }\end{array}$ \\
\hline 69 & Sq. $2 \mathrm{G}$ & 47 & 52 & $\begin{array}{l}\text { Cache pit that contained two } \\
\text { small celts, an adze or } \\
\text { fleshing tool, two hammer- } \\
\text { stones, one piece of } \\
\text { sandstone, one gorget-like } \\
\text { piece of slate, a small, thin } \\
\text { piece of limestone, two side- } \\
\text { notched arrowpoints, a group } \\
\text { of chert flakes, and a deer } \\
\text { ulna knapping tool. Feature } \\
\text { dates to the early McCurtain } \\
\text { phase occupation. (See Figure } \\
\text { 4f-j). }\end{array}$ \\
\hline
\end{tabular}

One feature (Feature 59, Square 2E) contained a dog burial at a depth of $52 \mathrm{~cm}$. Dog burials are commonly found on Caddoan sites throughout Northeast Texas, and a small dog cemetery was excavated in 1991-1992 at the Roitsch (41RR16) site by the Texas Archeological Society. 


\section{Artifact Assemblage ${ }^{2}$}

\section{The Form and Design of the Ceramics}

The ceramics from the Rowland Clark site include jars, bottles, and bowls. ${ }^{3}$ In the discussion that follows, I will discuss each of the vessel forms and how they changed through time in shape, rim treatment, and decoration.

The jars at the site principally include the McKinney Plain, Nash Neck-Banded, and Emory Punctated-Incised types, although a portion of a Canton Incised jar was recovered in Feature 67. There is little change during the McCurtain phase occupation of Rowland Clark in the jars.

In the early McCurtain phase, the Nash Neck-Banded jars were usually rounded to globular in shape and decorated with straight or broken incised lines comprised of dashes (see Figure $7 \mathrm{a}, \mathrm{g}$ ). In some cases, a vertical incised line extended from a horizontal incised line on the shoulder to one near the base. Later in the phase, the incised lines were replaced by four equally spaced appliqued or engraved triangles (plain, notched, or chevron leaf-like designs [see Figure 7f] that extended downward from the shoulders; in a few cases, the upper body is incised or engraved as well. Jars also became more elongated, with vertical rims, and by ca. A.D. 1700 they had a melon shape with highly everted rims.

Up to ca. A.D. 1650, jars often had castellated rims; this is particularly the case from ca. A.D. 1300-1450. These rims had four equally-spaced peaks or high points. Jar handles changed from loop and strap handles to lugs and closed decorative appliqued designs by late McCurtain times.

Emory Punctated-Incised jars dating from ca. A.D. 1300-1450 had fingernail punctates (see Figure $4 \mathrm{k}$ and Figure $7 \mathrm{~b}-\mathrm{c}$ ) or pinching. Later examples had angular punctations probably made with stone flakes, sharp sticks, or cane.

Plain bottles and Avery Engraved bottles with carinated bodies and straight necks are indicative of early and late McCurtain phase ceramics. By ca. A.D. 1650-1700, bottle decorations changed to Hudson Engraved and Keno Trailed, and the bottles had spool necks. The early Avery Engraved bottles have fine engraved lines, and the lines may be filled with red pigment.

A painted bottle was found in Burial 13 that has grog temper. It is buff in color with a tall, straight red-painted neck and three large painted dots on the body (see Figure 8g). It resembles painted Middle Mississippi period bottles from northeast Arkansas and southeast Missouri.

The Rowland Clark bowls have considerable variation in size, shape, and decoration. Many of the plain bowls have flat bottoms and V-shaped sides similar to the bowls found in the Sanders phase; in fact, Sanders-like vessels constitute a goodly part of the plain pottery in the early McCurtain phase.

\footnotetext{
2 Other than pottery sherds, bones, and small cobbles and pebbles, few artifacts of note were found in the excavations outside of features. They include: Gary points (squares $1 \mathrm{E}, 4 \mathrm{D}, 6 \mathrm{C}$, and 7A); unidentified sidenotched (1E), corner-notched (4G), stemmed (7B), and contracting stem $(1 \mathrm{H})$ arrow points; Alba arrow point $(3 \mathrm{G})$; Agee arrow points $(3 \mathrm{G}, 5 \mathrm{~B})$; a cobble anvil $(1 \mathrm{H})$; manos $(1 \mathrm{H}, 2 \mathrm{G}, 3 \mathrm{C}, 7 \mathrm{D})$; sandstone and ferruginous sandstone abraders $(1 \mathrm{H}, 4 \mathrm{~B}, 5 \mathrm{~F}, 5 \mathrm{H}, 6 \mathrm{C}, 6 \mathrm{~F}[2], 6 \mathrm{aa})$; hammerstones $(2 \mathrm{~F}, 3 \mathrm{D}, 3 \mathrm{E}, 5 \mathrm{aa})$; hematite with abraded surfaces $(6 \mathrm{aa})$; celts and celt preforms $(2 \mathrm{H}, 3 \mathrm{~A}, 3 \mathrm{D}, 4 \mathrm{~B}, 4 \mathrm{~F}, 5 \mathrm{~A}, 5 \mathrm{H}, 5 \mathrm{aa}, 6 \mathrm{~B}, 6 \mathrm{~F}$, 6G, 6aa, 6bb, 7B, 7aa, 7bb, and 8A); quartz crystal (3D); quartz cobble (6F); limonite slab (5E); flat sandstone slabs (5bb[2]); a rectangular stone (6bb); utilized flake (2G); Coles Creek Incised rim (5E); Red River pipe, variety Haley (5E); pottery disk (4F, 5G, 6H, 6cc); clay earplug (2G, 5L); and mud-dauber nests $(2 F, 5 G)$.

${ }^{3}$ Although Perino does not discuss the temper of the Rowland Clark ceramics, inspection of the collections at the Museum of the Red River indicates that it is primarily shell-tempered; in some cases, a shelltempered grog was employed as an aplastic [Editor's note].
} 
Engraved carinated bowls with constricted necks and flaring rims have several different kinds of decorations during the early McCurtain phase. One unslipped bowl (Burial 4) had a castellated rim, strap handles, and fingernail punctates on the collar and rim (Figure 9c). This form loses the handles and punctates, instead having a red slip with the Avery Engraved decoration (classic early form is similar to the sunrise motif) on the shoulders. Burial 7 had a classic, but unslipped, Avery Engraved form with a scalloped rim (Figure 9e). Scalloped rims are restricted to the early McCurtain phase, and likely were derived from Sanders phase ceramics. Burial 6, by contrast, had two different Avery Engraved bowls: one with a castellated rim and loop handles and an almost vertical neck, and the other with a carinated body, straight neck, and scalloped rim (Figure 9d, f).

Tall, conical Avery Engraved bowls developed first from elongated V-shaped bowls (common in the earlier Sanders phase) with two forms: (1) with a plain, vertical rim; and (2) one with a short, angular or carinated rim (the Simms-like form; as this form was later used for deep, conical bowls with Simms Engraved decorations). The latter variety often had scalloped rims (Figure 10a-b).

The vertical rimmed variety became more common through time, and between ca. A.D. 1300-1450, these bowls had wide mouths with the Avery Engraved decoration extending from the rim down two-thirds its height (Figure 11a-d). Rarely, the carinated rim bowl form had a narrow Avery Engraved decoration on the narrow shoulder (see Figure 10d); this was later replaced by the Simms Engraved decoration.

From about A.D. 1450-1650, the tall, conical bowls developed slightly narrower orifices, and the Avery Engraved decoration covered only about 33 percent of the upper rim area (Figure 12). This late form of the tall, conical bowl appears first in the Burial 17 assemblage, about the same time the scalloped rim edges are no longer made with the Simms vessels. After ca. A.D. 1650, the sides of the bowls curve outward at the rim, and scroll-like Hodges Engraved and Taylor Engraved motifs replace them on these vessel forms (see Figure 12e).

As mentioned above, some early Simms type bowls had Avery Engraved decorations on the shoulders of the narrow, inverted rims, but they soon had their own distinctive design elements (Figure 13i). Simms bowls differ from Avery Engraved bowls in that the former have a short, angular offset rim, while the latter have straight rims.

The shallow, carinated bowls at Rowland Clark occur with Avery Engraved designs (see Figure 13e), with a variety of Simms Engraved, and as a ceramic variety we are tentatively referring to as Clark Engraved. Clark Engraved carinated bowls are a common bowl form during the early McCurtain phase.

The engraved motifs on Clark Engraved have four or (rarely) five panels on the shoulder decorated with an upper and a lower double line filled with groups of short vertical lines or cross-hatching. Panel ends may be rounded with the curves back-to-back in reverse parentheses, or with the line ends pointing towards each other to form partial circles (see Figure 13a, c-d, f-h). The S-shaped motif is sometimes featured in design elements as well. Figure 14a-h illustrates the most common Clark Engraved designs.

Clark Engraved bowls frequently have four small and outward projecting sprocketlike lugs on the vessel rim; the sprocket-like lugs slant from the top of the sprocket to the base of the next adjoining sprocket. Some Clark Engraved bowls have small, flattened lugs on the rim, and others have an extra sprocketed rim (see Figure 13f).

An assortment of other small bowl forms were identified at the Rowland Clark site, including noded bowls, effigy bowls, and bowls with castellated rims and lug handles (Figure 15). These bowls occur almost exclusively in the early McCurtain phase burials at the site. 


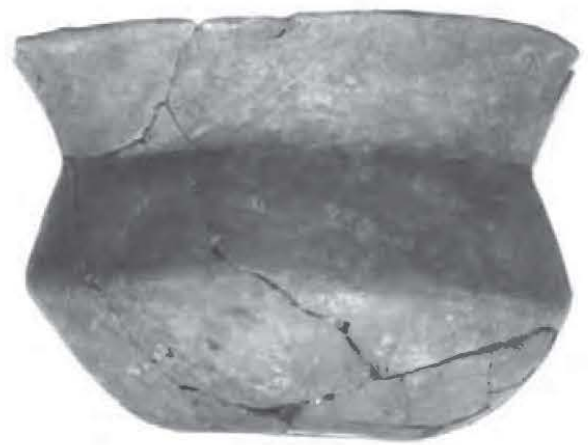

A
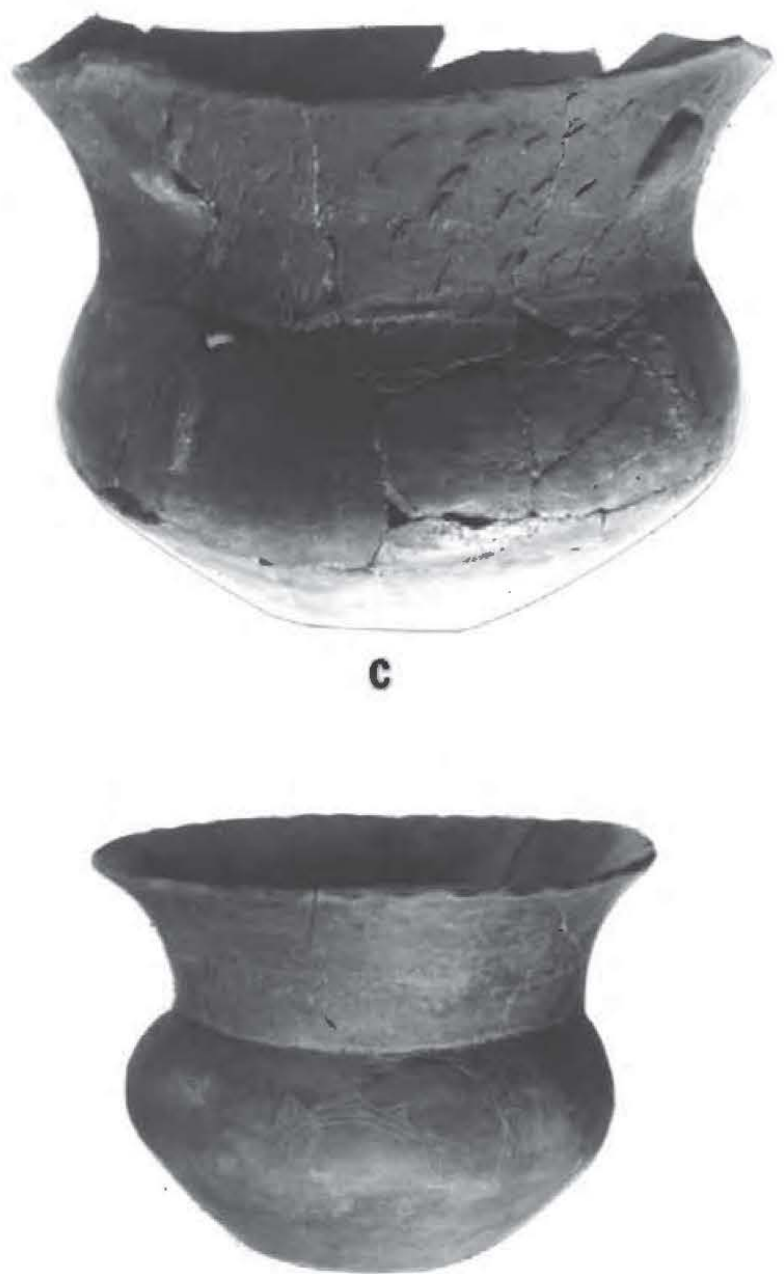

E

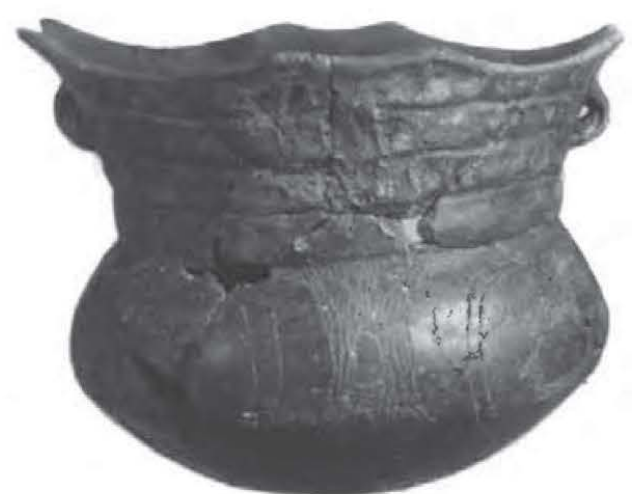

B
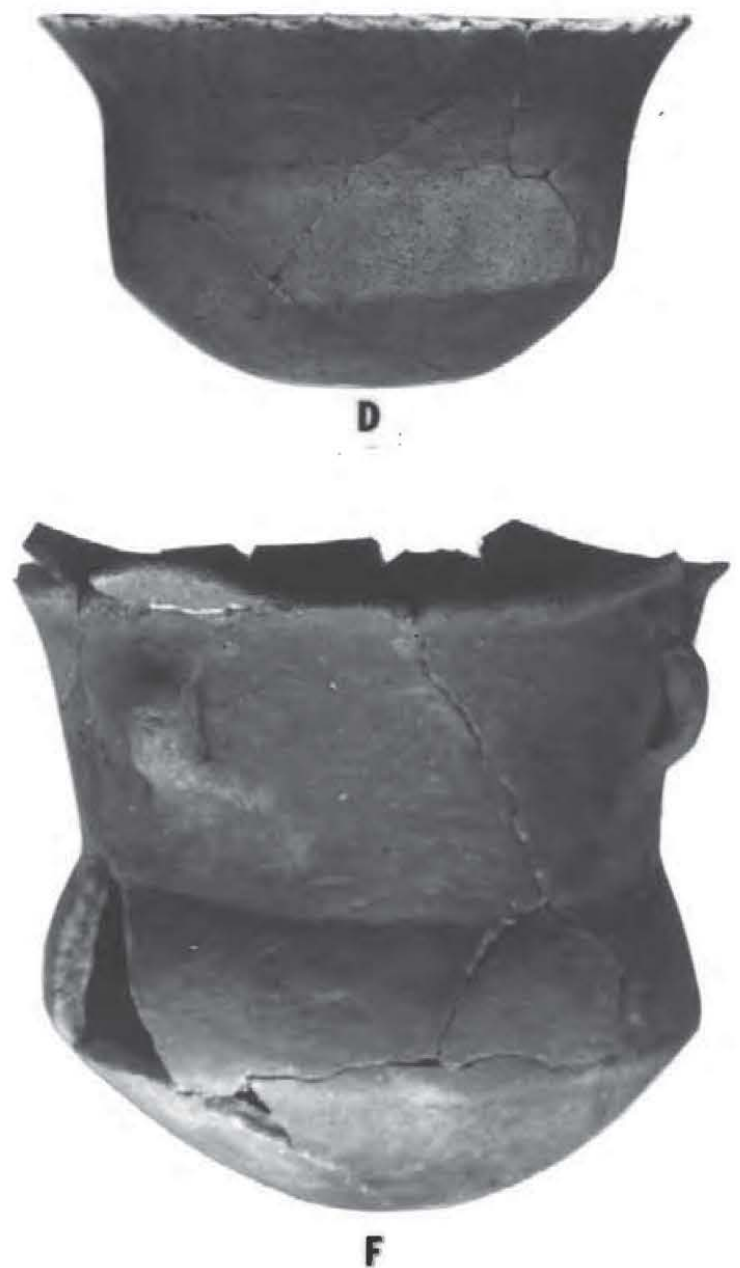

Figure 9. Early McCurtain phase carinated bowls: a, plain bowl, burials 10/11; b, Avery Engraved bowl, Burial 16; c, Emory Punctated-Incised bowl, Burial 4; d, plain bowl, Burial 6; e, Avery Engraved bowl, Burial 7; f, plain bowl, Burial 6. 


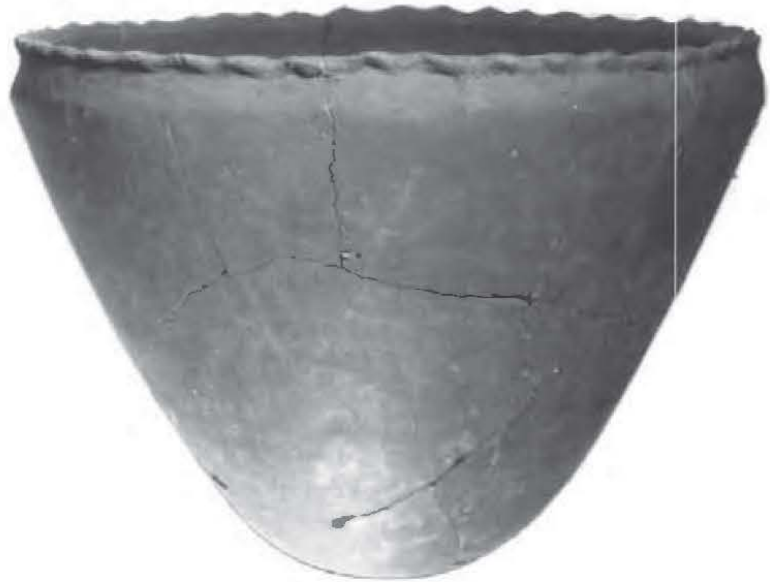

A
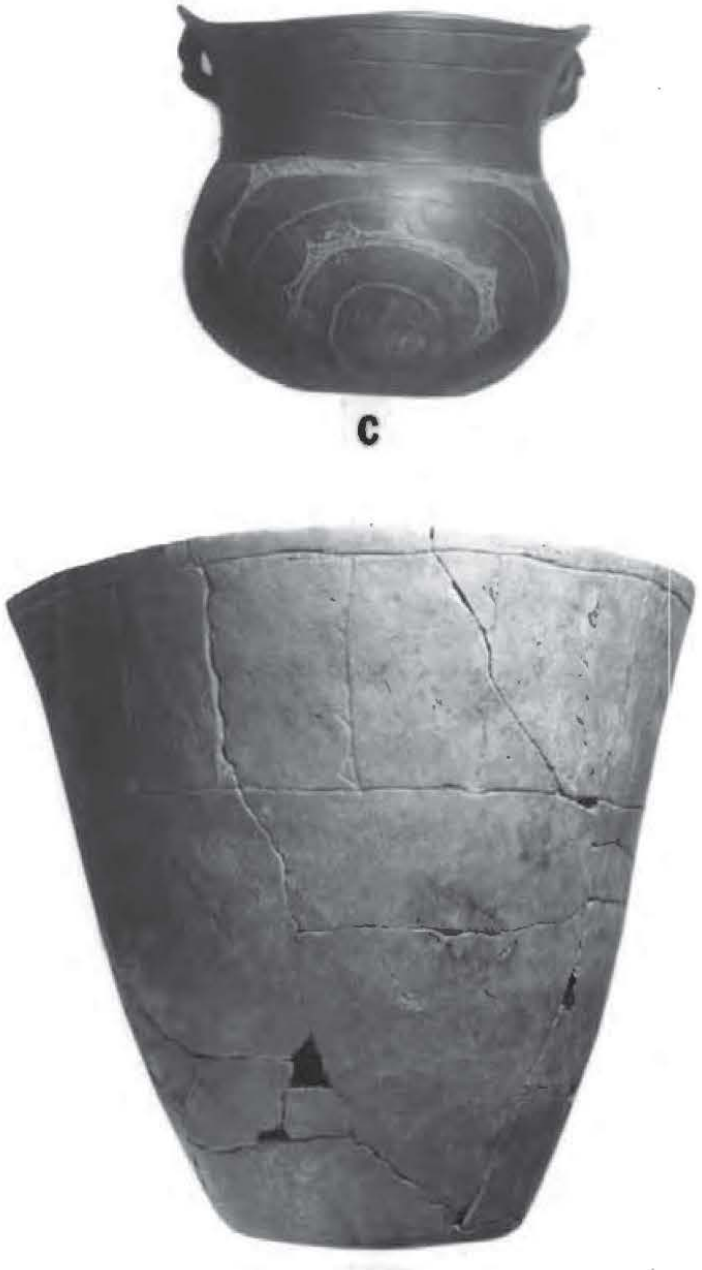

E

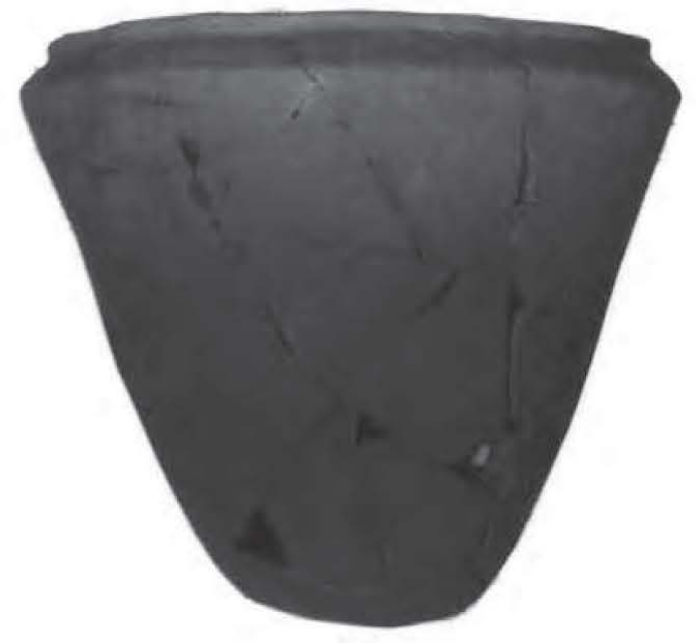

B
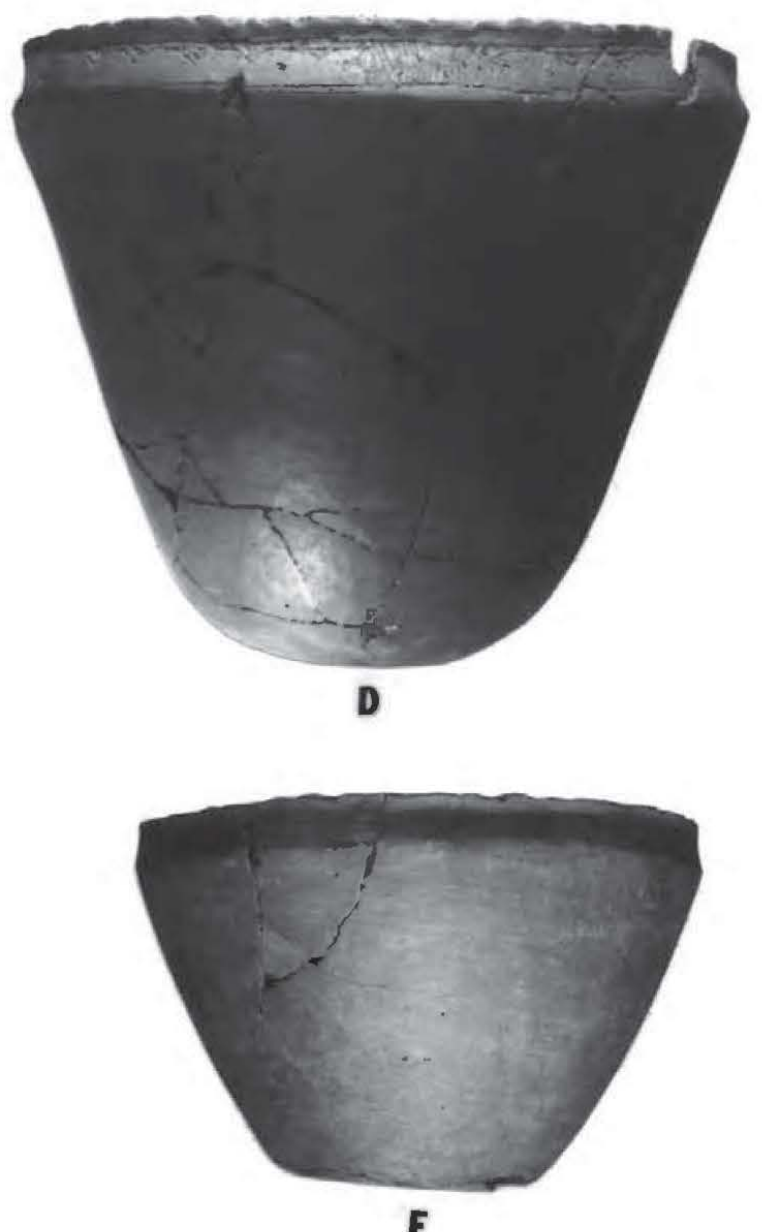

$\boldsymbol{F}$

Figure 10. Early McCurtain phase vessels: a, Red carinated rim-conical bowl with scalloped rim, Burial 7; b, Avery Engraved carinated rim-conical bowl, Burial 15; c, Avery Engraved jar found in the mound; d, Avery Engraved carinated rim-conical bowl, Burial 12; e, Avery Engraved conical bowl, Burial 25; f, Plain red carinated rim-conical bowl, Burial 28. 

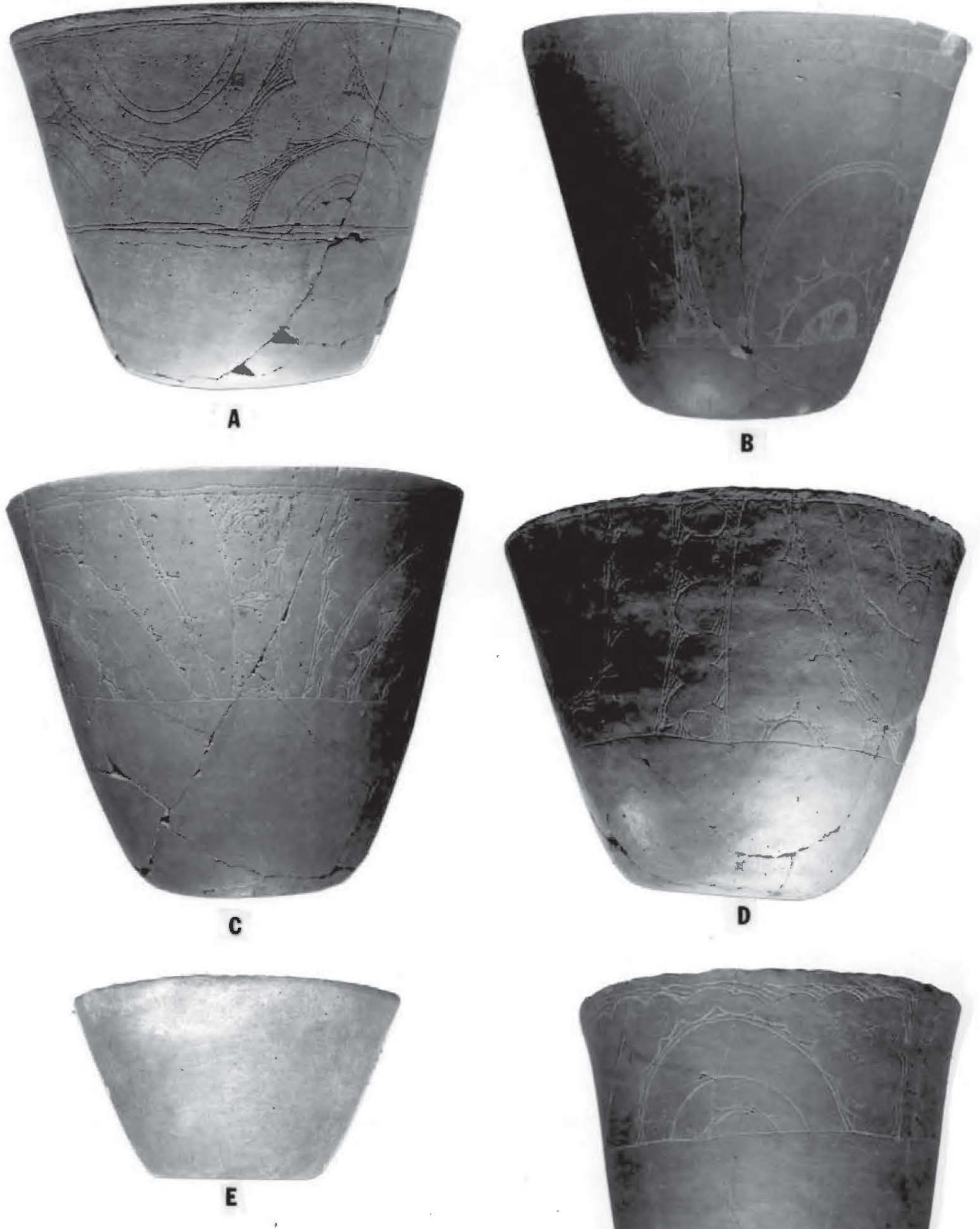

Figure 11. Early McCurtain conical and red-slipped Avery Engraved bowls: a, Burial 3; b, Burial 7; c, Burial 8; d, Burial 12; e, Burial 9; f, Burial 18.

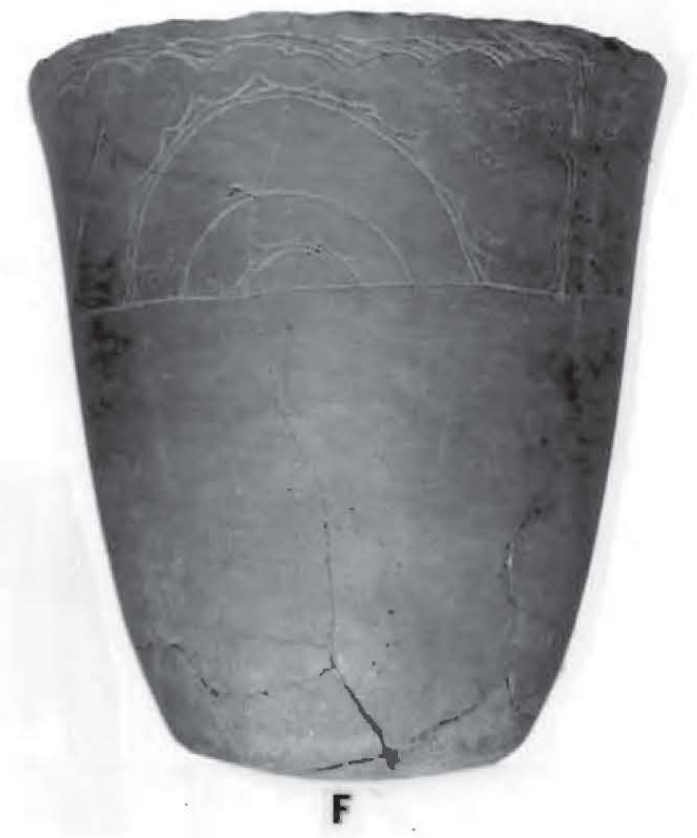



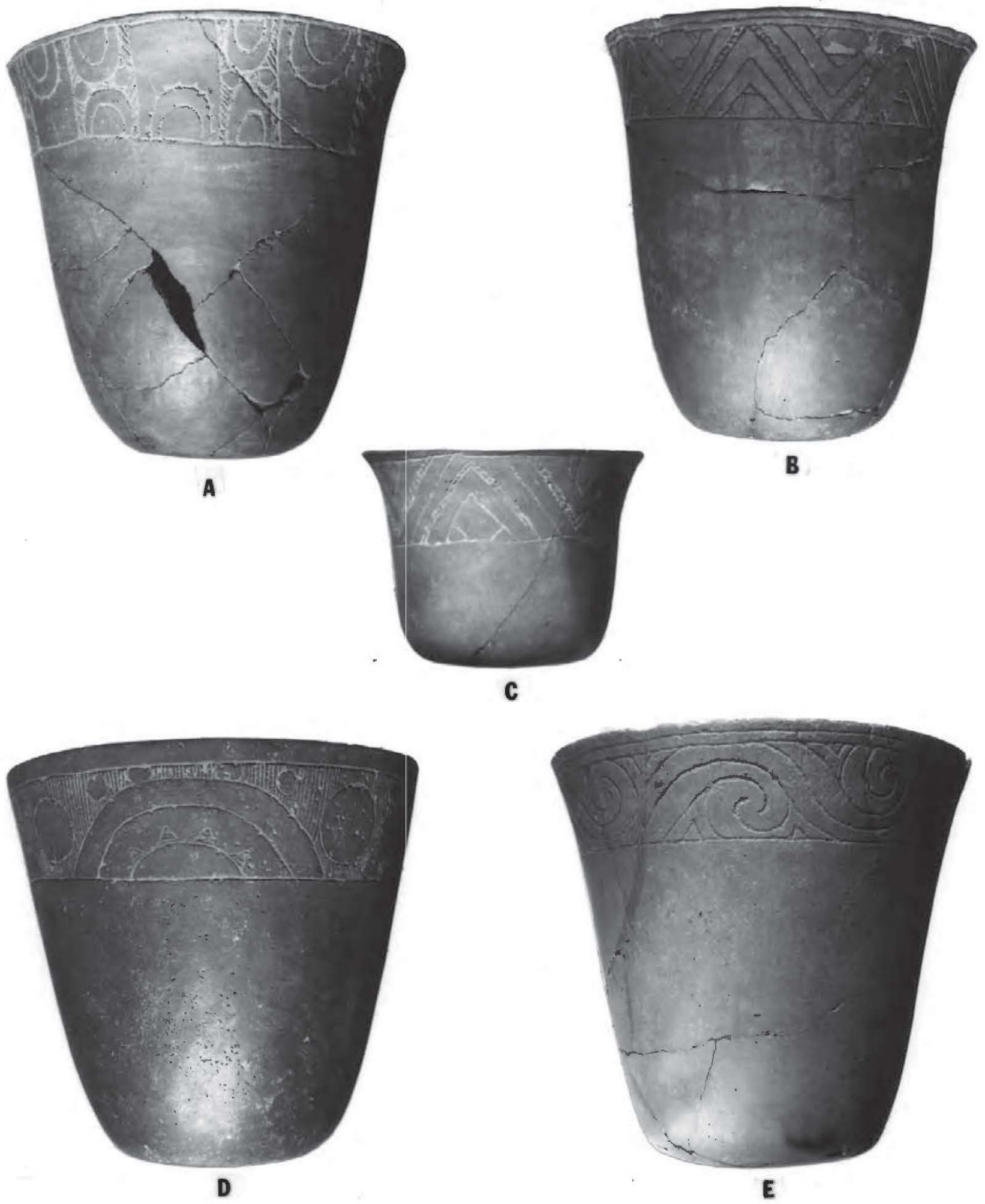

Figure 12. Late McCurtain phase Avery Engraved conical bowls: a, Burial 29; b, Burial 27; c, Burial 26; d, Burial 23; e, Burial 36. Note: b, c, and e are similar to bowls found at the Roden and Williams-Kaufman sites. 

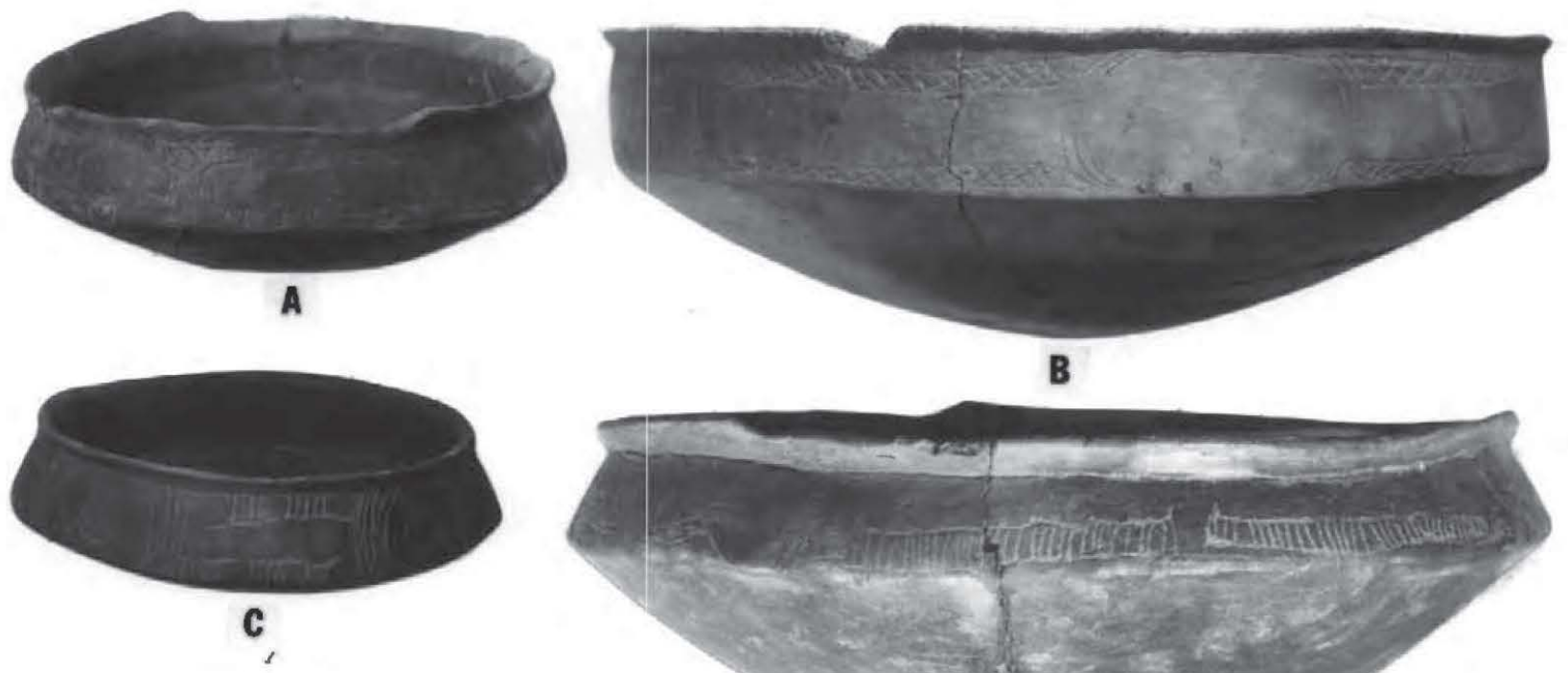

B

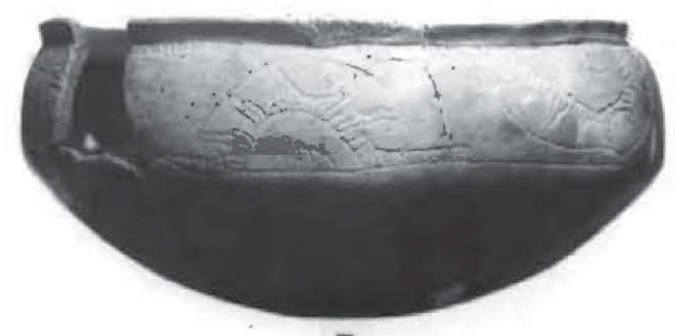

E

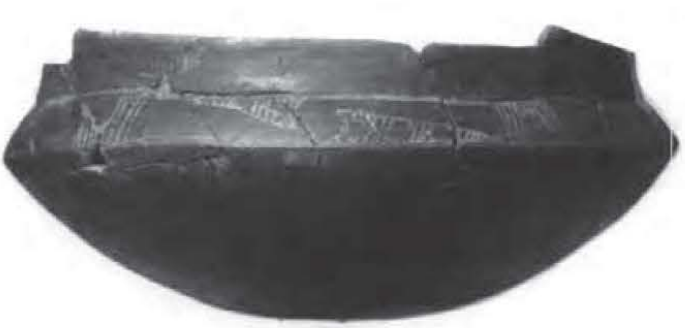

F
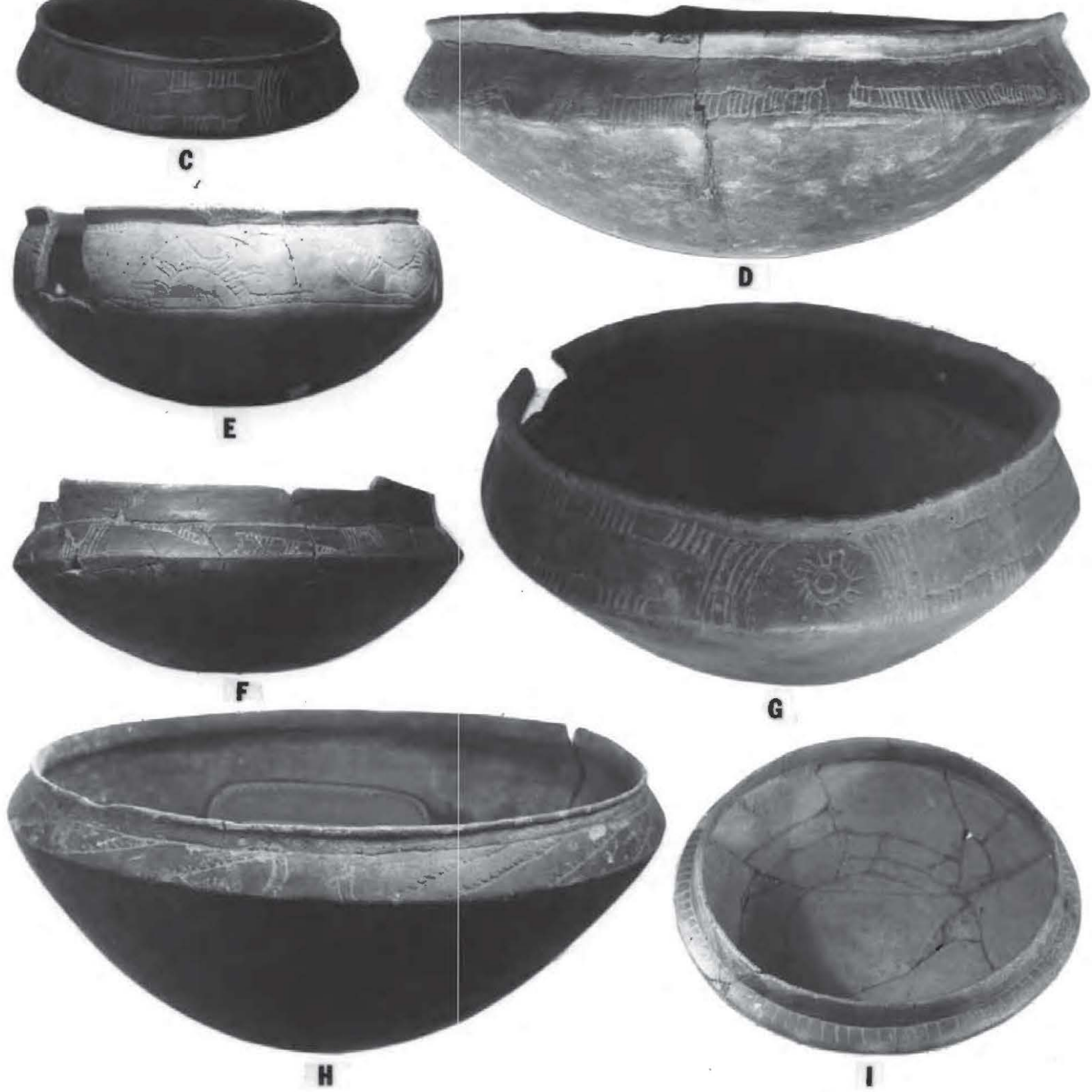

Figure 13. Shallow Carinated bowls: a, d, Clark Engraved, Burial 6; b, Clark Engraved, Burial 7; c, Clark Engraved, Burial 20; e, Avery Engraved, Burial 4; f, Clark Engraved, Burial 15; g, Clark Engraved, Burial 20; h, Avery Engraved, Burial 22; i, Simms Engraved, Burial 27. 

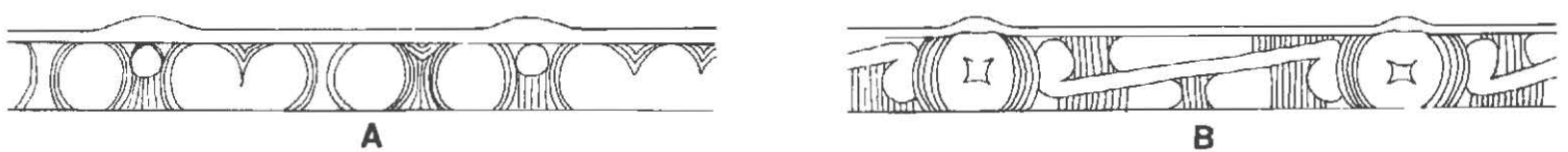

B
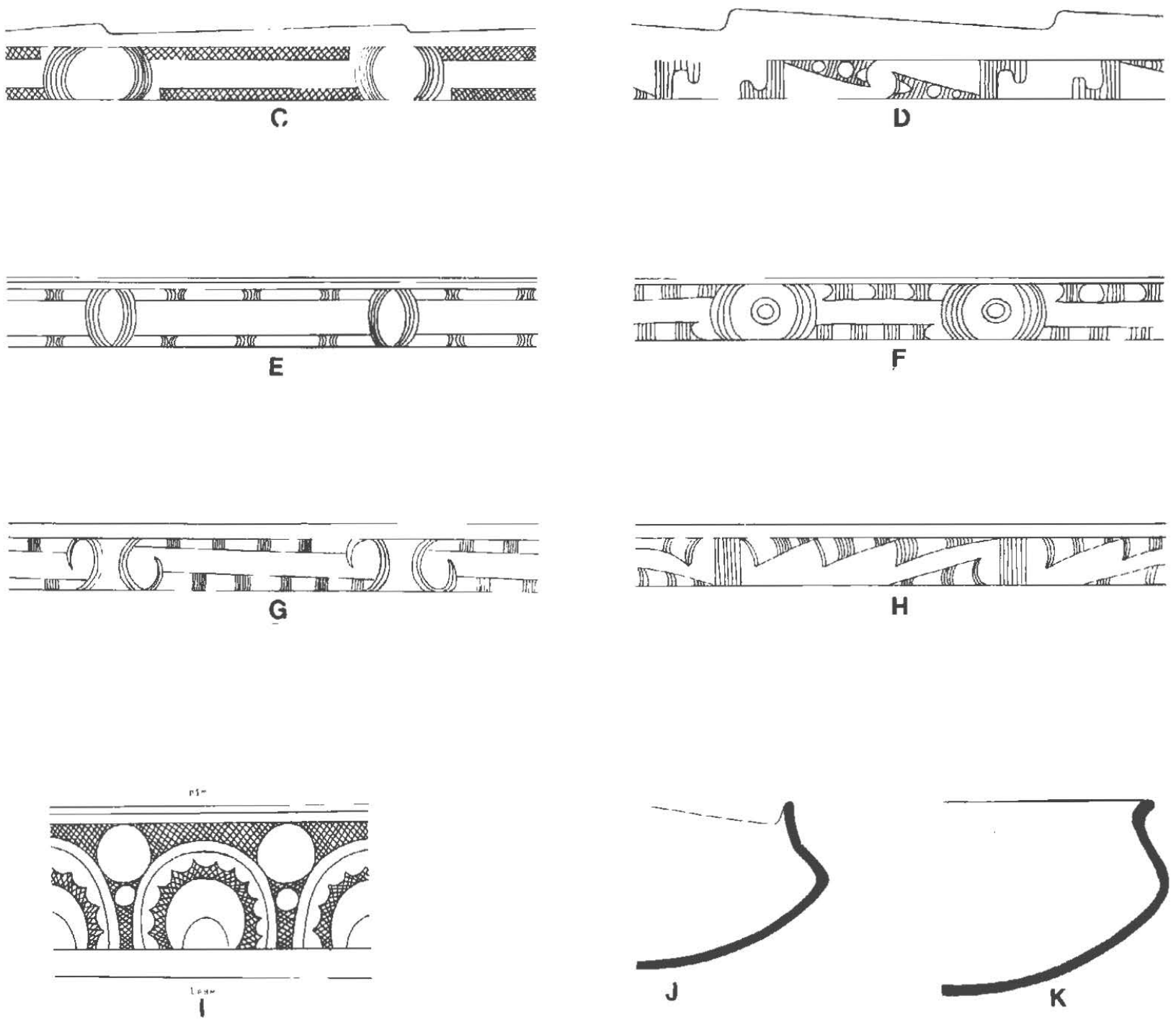

Figure 14. Bowl Decorations and Profiles: a-h, Clark Engraved decorative elements; i, Natchitoches Engraved-like design on a V-shaped bowl; j-k, Clark Engraved bowl profiles. 


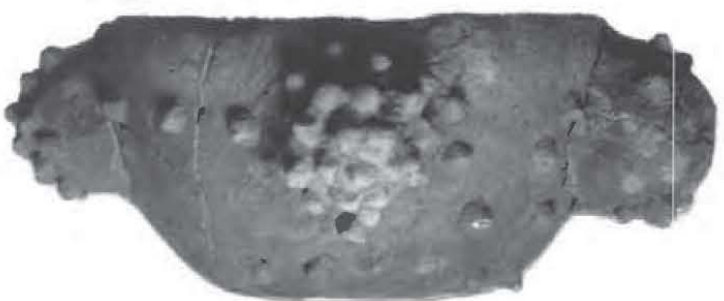

A
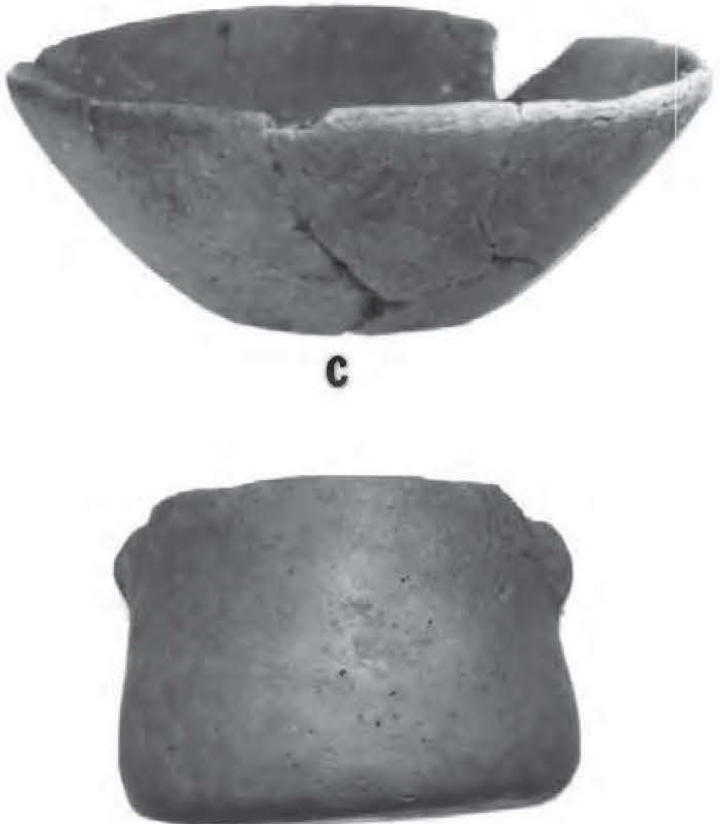

E

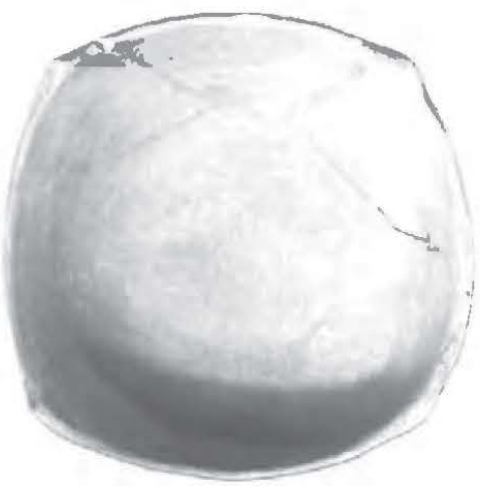

G

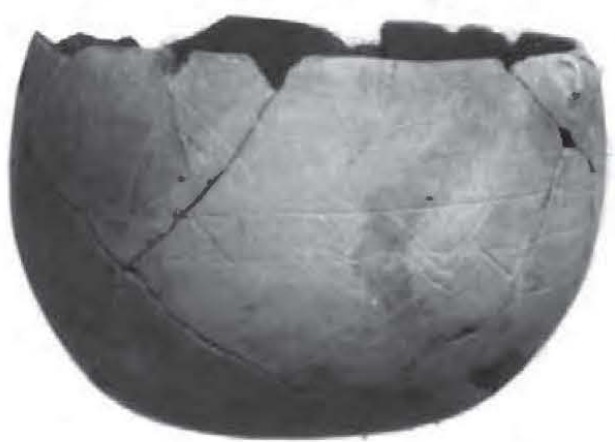

B

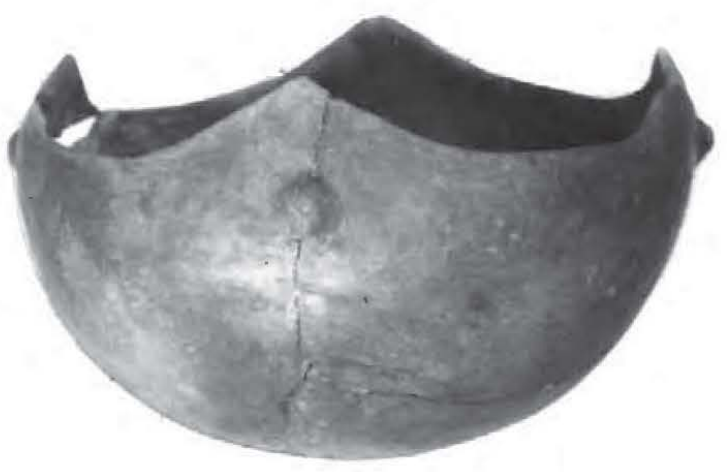

D
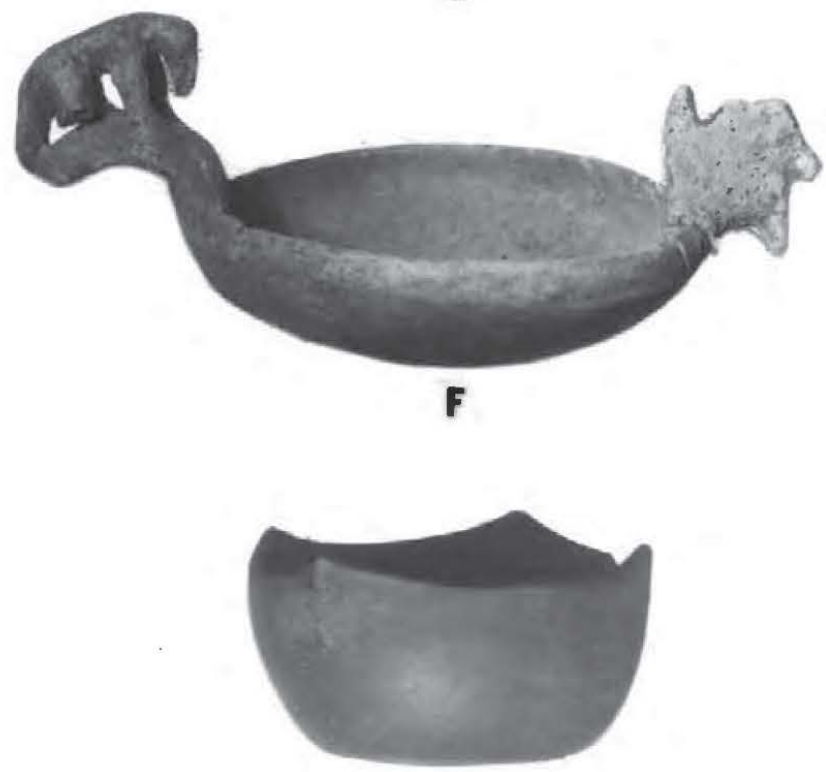

H

Figure 15. Assorted Small bowl forms: a, noded bowl with rattle lobes, Burial 10/11; b, incised bowl, Burial 1; c, V-shaped bowl, Burial 1; d, bowl with castellated rim and a node under each peak, Burial 3; e, slipped bowl with lug handles, Burial 9; $\mathrm{f}$, tail-rider bowl with bird head and animal effigy figure on the tail, Burial $17 ; \mathrm{g}$, top view of $\mathrm{h} ; \mathrm{h}$, bowl with four castellations, Burial 3. 


\section{Clay Pipes}

Clay pipes were present in 13 burials at Rowland Clark. The early McCurtain phase pipes were plain (Figure $16 \mathrm{~g}$ ), and generally resembled the Haley variety of the Red River pipe defined by Hoffman (1967). They were different, however, in having an abbreviated stem designed to take a reed or wooden stem rather than the clay stem integral to the Haley pipes. The later McCurtain phase pipes were elbow forms (Figure 16d-e). One late pipe had an engraved decoration on it identical with decorations found on Taylor Engraved ceramics from the site (Figure 16a).

\section{Pottery Disks}

This artifact category includes one complete and three fragmentary specimens from the McCurtain phase village area. They may have been used as spindle-whorls.

\section{Clay Earplugs}

Untempered, baked clay earplugs are seldom found on Caddoan sites along the Red River; one was recovered from a late McCurtain phase burial at the Bob Williams site (Perino 1983). The two earplugs were in what may have been different postmolds.

The earplugs are about $1.6 \mathrm{~cm}$ in length, $1.9 \mathrm{~cm}$ wide at the mushroomed face end, and approximately $1.6 \mathrm{~cm}$ wide at the mushroomed basal end (see Figure $4 \mathrm{a}-\mathrm{b}$ ). The central column is constricted to $1.3 \mathrm{~cm}$ in diameter. Although the actual use of these specimens is unclear, they may have used as "training" plugs to keep holes in pierced ears open when the more decorative shell disk type of ear plug was used as an ornament.

\section{Chipped and Ground Stone}

This artifact category includes dart points, arrow points, celts, and ground hematite; scrapers, cutting tools, and utilized flakes were rare. The dart points consist of a few small Gary points, while the arrow points were found in numbers only with the burials.

Four main types of Caddoan arrow points were recovered from Rowland Clark: the Scallorn sattler, Washita peno, Maud, and Talco types. The varieties of Scallorn and Washita arrows (cf. Brown 1976) occur in the early McCurtain phase graves, along with one Haskell arrow point. The triangular Maud and Talco arrows characterize the late McCurtain phase, although one Bassett was found in Burial 36.

The Scallorn sattler arrow is most frequent in the early McCurtain phase; the Washita peno variety is relatively rare in the area, and has not been found as the sole arrow point type in mortuary contexts in the middle Red River. Also during this time, some corner-notched arrow points that had the stems broken off were reworked and hafted as triangular points. Many of the Scallorn specimens were made on curved flakes with only one well-chipped side; the other side often showed a broad flake scar. The later triangular arrows were completely chipped on both sides of relatively straight flakes.

The triangular arrows at Rowland Clark ranged from having needle-like tips and concave basal edges (Maud), to simple triangles (resembling the Fresno type), to arrows with a broad, concave basal edge and an accentuated needle tip (Talco). A few Maud points have rudimentary side notches (see Figure 6a); triangular arrows with the same style of notching have been recovered on contemporaneous Titus phase sites in the Cypress Creek basin (Turner 1978).

There appear to be regional changes in the types of cherts used for making arrow points during the McCurtain phase. During the early McCurtain phase (at Rowland Clark as well as the Roitsch, Bob Williams, and Roden sites), cherts preferred included novaculite, siltstone, Battiest chert, Big Fork chert (black and green varieties), Woodford chert, and various cobble cherts; these Ouachita Mountains materials could all be gathered in the Red 

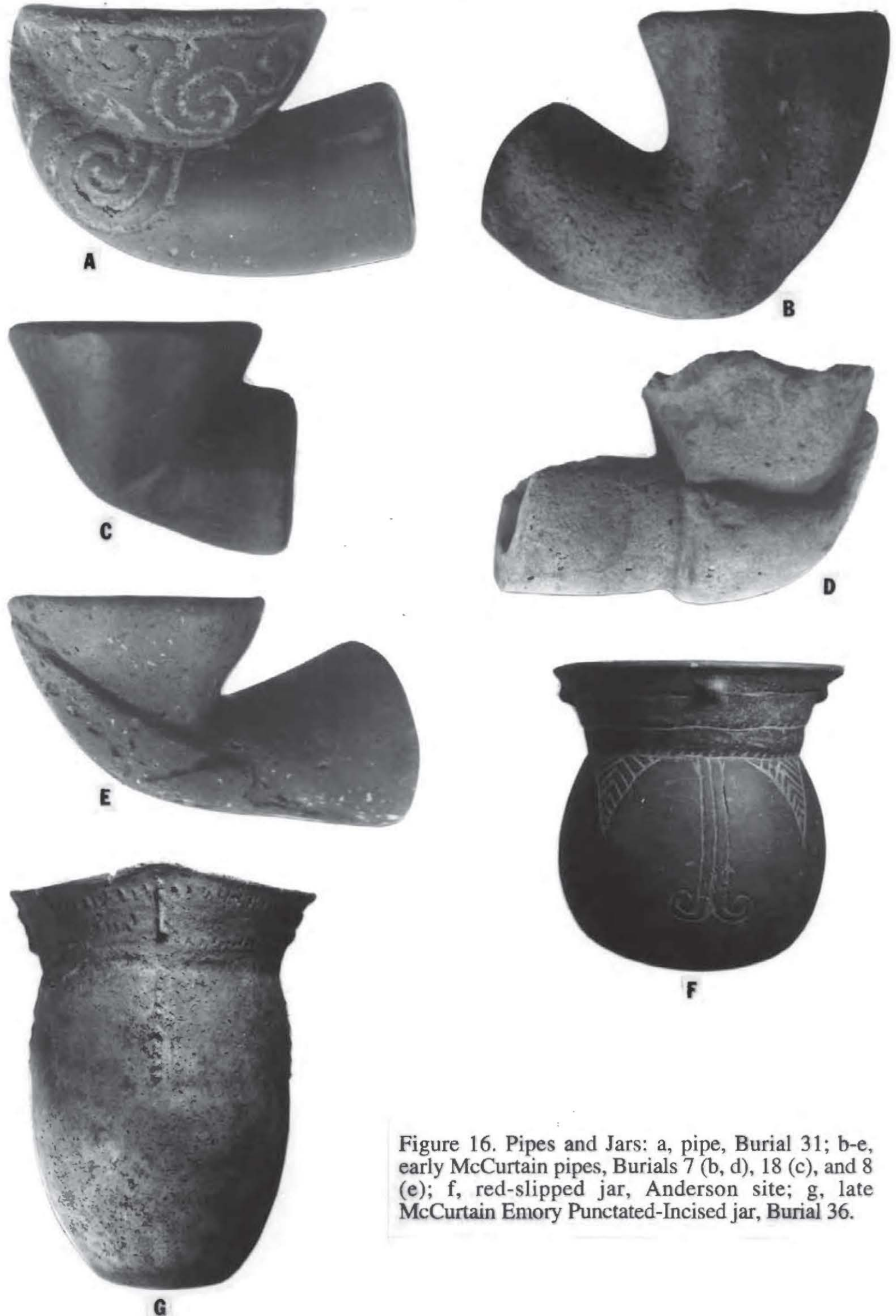

Figure 16. Pipes and Jars: a, pipe, Burial 31; b-e, early McCurtain pipes, Burials 7 (b, d), 18 (c), and 8 (e); f, red-slipped jar, Anderson site; g, late McCurtain Emory Punctated-Incised jar, Burial 36. 
River gravels below the mouth of the Kiamichi River, or in the Red River downstream from the Glover and Mountain Fork rivers (Banks 1990). Some of the cherts (deep, translucent brown in color) resemble Edwards chert from Central Texas. Ogallala quartzite was the dominant material used for producing Maud and Talco arrows in the late McCurtain phase. The Caddo appear to have heat-treated the fine-grained quartzite, as the arrow points on this material were well made and finely flaked.

Many of the celt preforms were made of local diorites that were first chipped to form, then ground and polished to finish the piece. Hatton Tuff and Colbert Creek diorite lithic debris is quite common on McCurtain phase sites in the middle Red River, indicating that celt manufacture was important in Late Caddoan times. As the local diorites were not particularly durable, and fractured easily, many celts needed to be made to satisfy the demand for these tools. Most Caddoan celts are roughly made, being essentially a stone, slab, or cobble with a bit for cutting. To make the celts last longer, the Caddo rounded the bits to have a more obtuse cutting edge; this lessened their cutting ability, however. Other celts were made of slate and slabs of Ouachita Mountains quartzite (Banks 1990; Banks and Winters 1975).

Finely-made celts are rare in the McCurtain phase, but are sometimes found with high-status burials. Well made celts are more common in Mississippian sites to the east and north where glacial diorite is found.

A possible slate celt with an offset bit more like an adze, or a fleshing tool, was placed with Burial 38, a historic Caddoan male burial (see Figure 5p). This tool had the angular form of the Avery Engraved decoration on either side of the poll; I doubt the tool was hafted like an adze as this would have obscured the decoration. If correct, it would have made an excellent fleshing tool, like those made from sections of deer leg bones. A similar slate tool was recovered in Feature 69, which contained an early McCurtain phase tool cache.

One ground hematite fragment was found in the Rowland Clark excavations. This material was probably used to make a red pigment for body decorations and for coloring pottery. On the Red River, hematite is often found as a mortuary offering with Caddo males.

\section{Bone Artifacts}

Most of the bone artifacts from Rowland Clark were found in mortuary contexts. ldentified tool forms include deer jaw picks (possibly used for excavating graves and pits), deer ulna knapping tools (in the Feature 69 tool cache and in early McCurtain phase burials), and sections of antler from tool knapping (Burial 25).

\section{Mud-Dauber Nests}

Two mud-dauber nests were recovered at the site. These wasps attached their mud nests to various parts of Caddoan houses, such as the timbers or thatch, and the impressions suggest one had been attached to poles about $2.5 \mathrm{~cm}$ in diameter, while the other had grass or thatch impressions.

\section{Food Remains}

Corn was obviously commonly used as food since charred corn cobs were numerous in the smudge pits at Rowland Clark (Blake, Appendix 1, this volume). Nuts were also an important part of the diet as many charred fragments of crushed hickory nuts were recovered as well.

The excavations at Rowland Clark uncovered evidence in the mortuary features for the inclusion of animal remains as grave good associations. One such offering included the bones of three small fish of the sunfish family with Burials 10 and 11. The bones of a gray 
squirrel were found in a ceramic bowl with Burial 38, while the bones of a songbird (sparrow or finch) were recovered in a bowl in Burial 34.

Bird and animal bones have been reported in, and under, ceramic vessels at other Red River Caddoan sites such as Bob Williams (Perino 1983) and Roden (Perino 1981). At the Haley site in southwest Arkansas, bird bones found in vessels with Burials 24 and 26 included one scarlet tanager, one yellow-billed cookoo. five red-eyed vireo, and two small birds of the Vireo species; the bones of a squirrel were found in a bowl in Burial 24 (Perino 1967).

\section{SUMMARY}

Our excavations at the Rowland Clark site were intended to document the habitation and mortuary features of Caddoan late McCurtain phase groups who occupied the site, and also to corroborate the archaeological information previously obtained from work at Roden (Perino 1981) and Bob Williams (Perino 1983). This was accomplished in part, but of equal significance was the discovery and excavation of a discrete early McCurtain phase cemetery where bioarchaeological information was obtained on ca. A.D. 1300-1450 lifeways, but also containing interesting typologically and stylistically developmental ceramic wares.

The early McCurtain phase cemetery contained 20 individuals in deep graves (and one in a house floor). The late McCurtain phase burials (including those dating to the midlate seventeenth century) consist of 18 individuals laid out with their heads to the west or west-northwest. Other contemporaneous McCurtain phase cemeteries had individuals oriented with heads to the east; this change in mortuary orientation cannot be explained at the present time, but perhaps it simply relates to strong local preferences. Most of the features and house remains at Rowland Clark appear to date to the early McCurtain phase. Their density in the excavation area clearly indicates intensive Caddoan use of the river terrace at that time.

The accompanying ceramics in the two cemeteries hint at their origins from various forms of Sanders phase pottery, but new types and vessel forms were developed as well. Avery Engraved, Simms Engraved, Clark Engraved, Nash Neck-Banded, McKinney Plain, and Emory Punctated-Incised types dominant the ceramics for about 350 years (ca. A.D. 1300-1650), while new styles and forms of engraved and incised bowls and bottles (Hudson Engraved, Hodges Engraved, Taylor Engraved, Keno Trailed) became popular after ca. A.D. 1650. A form of red-slipped jar with a distinctive design element (left and right curlicues and pendant engraved triangles filled with chevrons [see Figure 16f]) appears to also be part of the ca. A.D. 1650-1700 occupation of the Rowland Clark site, as this identical form and design has been found in Burial 20, House 2 at the Bob Williams site in association with an iron strike-a-lite (Perino 1983). ${ }^{4}$

\section{Acknowledgments}

Appreciation is expressed to the many people who have been involved in the excavations at the Rowland Clark site, and in the preparation of this report. Quintus and Mary Herron, founders of the Herron Research Foundation, Inc., who established the Museum of the Red River as a City of Idabel institution, sponsored the excavations. Mary Elizabeth Good proof read and organized the original manuscript.

4 This distinctive jar form/design has also been found at the Roden site by the landowner, two were recovered at Bob Williams, one from the Anderson site, and another is in the Lemley Collection (Hope, Arkansas), having been washed out with a burial at the McKean site on the Cossatot River ca. $15 \mathrm{~km}$ northeast of DeQueen, Arkansas. Harris (1953:Plate 8, No. 5) illustrates a vessel from Burial 2 at the Kaufman (Roitsch) site with the identical motif. 
Participants of the Museum's annual adult field school held at Rowland Clark worked hard to recover the information and materials reported on herein. They were: a group of students from Lincoln Land College, Springfield, Illinois, consisting of Professor Harold Clements, Jr., Evan Kirk, Michael Pasenko, Sally Thompson, and David Farrar. Others from Illinois included Charles Laster, East Alton; Harry and Ruth Myers, Downers Grove; David Klostermeir, Worden; and John C. Smith and Ray Fraser, Schaumburg. Those from Texas were David Watkins, Longview; and Gary Sykes, Larry Keith, and Dave and Cindy Wright, Paris. Those from Oklahoma included Bill Campbell, Robert Chapman, and Mrs. Doris Perkins and five students, Idabel; Si Sisemore, Salina; R. D. Bennett, Pawhuska; Claude Long and Granville Morgan, Oklahoma City; and Victoria Mills, Durant.

\section{References Cited}

Banks, Larry D.

1990 From Mountain Peaks to Alligator Stomachs: A Review of Lithic Sources in the Trans-Mississippi South, the Southern Plains, and Adjacent Southwest. Memoir No. 4. Oklahoma Anthropological Society, Oklahoma City.

Banks, Larry D. and Joe Winters

1975 The Bentsen-Clark Site, Red River County, Texas: A Preliminary Report. Special Publication, No. 2. Texas Archeological Society, San Antonio.

Binford, Lewis R.

1967 Smudge Pits and Hide Smoking: The Use of Analogy in Archaeological Reasoning. American Antiquity 32:1-12.

Brown, James A.

1976 Spiro Studies, Volume 4: The Artifacts. The University of Oklahoma Research Institute, Norman.

Bruseth, James E.

1994 The Development of Caddoan Polities along the Middle Red River Valley of Eastern Texas and Oklahoma. In The Native History of the Caddo:Their Place in Southeastern Archaeology and Ethnohistory, edited by Timothy K. Perttula and James E. Bruseth. MS in submission.

Harris, R. King

1953 The Sam Kaufman Site, Red River County, Texas. Bulletin of the Texas Archeological Society 24:43-68.

Hoffman, Michael P.

1967 Ceramic Pipe Style Chronology along the Red River Drainage in Southwestern Arkansas. The Arkansas Archaeologist 8(1):4-14.

Munson, Patrick J.

1969 Comments on Binford's "Smudge Pits and Hide Smoking: The Use of Analogy in Archaeological Reasoning." American Antiquity 34:83-85.

Perino, Gregory

1966 The Banks Village Site. Memoir 4. Missouri Archaeological Society, Columbia.

1967 Report on Field Burials 24, 26, and 28 at the Haley Place, Miller County, Arkansas. Oklahoma Anthropological Society Newsletter 15(5). 
Perino, Gregory

1981 Archaeological Investigations at the Roden Site, McCurtain County, Oklahoma. Museum of the Red River, Idabel, Oklahoma.

1983 Archaeological Research at the Bob Williams Site, Red River County, Texas. Museum of the Red River, Idabel, Oklahoma.

Schambach, Frank F.

1982 An Outline of Fourche Maline Culture in Southwest Arkansas. In Arkansas Archeology in Review, edited by Neal L. Trubowitz and Marvin D. Jeter, pp. 132197. Research Series No. 15. Arkansas Archeological Survey, Fayetteville.

Story, Dee Ann

1990 Cultural History of the Native Americans. In Archeology and Bioarcheology of the Gulf Coastal Plain, by Dee Ann Story, Janice A. Guy, Barbara A. Burnett, Martha D. Freeman. Jerome C. Rose, D. Gentry Steele, Ben W. Olive, and Karl J. Reinhard, pp. 163-366. 2 Vols. Research Series No. 38. Arkansas Archeological Survey, Fayetteville.

Turner, Robert L., Jr.

1978 The Tuck Carpenter Site and its Relations to Other Sites Within the Titus Focus. Bulletin of the Texas Archeological Society 49:1-110. 